\title{
Technical Note: Development of chemoinformatic tools to enumerate functional groups in molecules for organic aerosol characterization
}

\author{
Giulia Ruggeri and Satoshi Takahama \\ ENAC/IIE Swiss Federal Institute of Technology Lausanne (EPFL), Lausanne, Switzerland \\ Correspondence to: Satoshi Takahama (satoshi.takahama@epfl.ch)
}

Received: 1 October 2015 - Published in Atmos. Chem. Phys. Discuss.: 27 November 2015

Revised: 4 March 2016 - Accepted: 9 March 2016 - Published: 11 April 2016

\begin{abstract}
Functional groups (FGs) can be used as a reduced representation of organic aerosol composition in both ambient and controlled chamber studies, as they retain a certain chemical specificity. Furthermore, FG composition has been informative for source apportionment, and various models based on a group contribution framework have been developed to calculate physicochemical properties of organic compounds. In this work, we provide a set of validated chemoinformatic patterns that correspond to (1) a complete set of functional groups that can entirely describe the molecules comprised in the $\alpha$-pinene and 1,3,5trimethylbenzene MCMv3.2 oxidation schemes, (2) FGs that are measurable by Fourier transform infrared spectroscopy (FTIR), (3) groups incorporated in the SIMPOL.1 vapor pressure estimation model, and (4) bonds necessary for the calculation of carbon oxidation state. We also provide example applications for this set of patterns. We compare available aerosol composition reported by chemical speciation measurements and FTIR for different emission sources, and calculate the FG contribution to the $\mathrm{O}: \mathrm{C}$ ratio of simulated gasphase composition generated from $\alpha$-pinene photooxidation (using the MCMv3.2 oxidation scheme).
\end{abstract}

\section{Introduction}

Atmospheric aerosols are complex mixtures of inorganic salts, mineral dust, sea salt, black carbon, metals, organic compounds, and water (Seinfeld and Pandis, 2006). Of these components, the organic fraction can comprise as much as $80 \%$ of the aerosol mass (Lim and Turpin, 2002; Zhang et al., 2007) and yet eludes definitive characterization due to the number and diversity of molecule types. There have been many proposals for reducing representations in which a mixture of $10000+$ different types of molecules (Hamilton et al., 2004) are represented by some combination of their molecular size, carbon number, polarity, or elemental ratios (Pankow and Barsanti, 2009; Kroll et al., 2011; Daumit et al., 2013; Donahue et al., 2012), many of which are associated with observable quantities (e.g., by aerosol mass spectrometry (AMS; Jayne et al., 2000), gas chromatography-mass spectrometry (GC-MS and GCxGC-MS; Rogge et al., 1993; Hamilton et al., 2004)). Molecular bonds or organic functional groups (FGs), which are the focus of this manuscript, can also be used to provide reduced representations for mixtures and have been shown useful for organic mass (OM) quantification, source apportionment, and prediction of hygroscopicity and volatility (e.g., Russell, 2003; Donahue, 2011; Russell et al., 2011; Suda et al., 2014). Examples of property estimation methods include models for purecomponent vapor pressure (Pankow and Asher, 2008; Compernolle et al., 2011), UNIFAC, and its variations for activity coefficients and viscosity (Ming and Russell, 2001; Griffin et al., 2002; Zuend et al., 2008, 2011). The FGs that can be detected or quantified by measurement vary widely by analytical technique, which include Fourier transform infrared spectroscopy (FTIR; Maria et al., 2002), Raman spectroscopy (Craig et al., 2015), spectrophotometry (Aimanant and Ziemann, 2013), nuclear magnetic resonance (NMR; Decesari et al., 2000; Cleveland et al., 2012), and gas chromatography with mass spectrometry and derivatization (Dron et al., 2010).

Projecting specific molecular information available through various forms of mass spectrometry (e.g., Williams et al., 2006; Kalberer et al., 2006; Laskin et al., 2012; Chan et al., 2013; Nguyen et al., 2013; Vogel et al., 2013; 
Yatavelli et al., 2014; Schilling Fahnestock et al., 2015; Chhabra et al., 2015) or model simulations employing explicit chemical mechanisms (e.g., Jenkin, 2004; Aumont et al., 2005; Herrmann et al., 2005) to a reduced dimensional space represented by some combination of FGs can be useful for measurement intercomparisons, or model-measurement comparisons. For this task, the aerosol community can benefit from developments in the chemoinformatics community. If the structure of a substance is described through its molecular (also referred to as chemical) graph (Balaban, 1985) - which is a set of atoms and their association through bonds - the abundance of arbitrary substructures (also called fragments) can be estimated through pattern-matching algorithms called subgraph isomorphisms (Barnard, 1993; Ehrlich and Rarey, 2012; Kerber et al., 2014). Structural information of molecules can be encoded in various representations, including a linear string of ASCII characters denoted as SMILES (Weininger, 1988). A corresponding set of fragments can be specified by SMARTS, which is a superset of the SMILES specification (DAYLIGHT Chemical Information Systems, Inc.). There are many chemoinformatic packages that implement algorithms for pattern matching - for instance, OpenBabel (O'Boyle et al., 2011), Chemistry Development Kit (Steinbeck et al., 2003), OEChem (Openeye Scientific Software, Inc.), RDKit (Landrum, 2015), and Indigo (GGA Software Services). The concept of using SMILES and SMARTS patterns has been reported for applications in the atmospheric chemistry community (Barley et al., 2011; COBRA, Fooshee et al., 2012). While some sets of SMARTS patterns for substructure matching can additionally be found in the literature (Hann et al., 1999; Walters and Murcko, 2002; Olah et al., 2004; Enoch et al., 2008; Barley et al., 2011; Kenny et al., 2013) or on web databases - e.g., DAYLIGHT Chemical Information Systems, Inc. (DAYLIGHT Chemical Information Systems, Inc.) - knowledge regarding the extent of specificity and validation of the defined patterns is not available.

In this work, we report specifications for four specific sets of substructures:

1. FGs contained in $\alpha$-pinene and 1,3,5-trimethylbenzene photooxidation products defined in MCMv3.2 (Jenkin et al., 1997; Saunders et al., 2003; Jenkin et al., 2003; Bloss et al., 2005), obtained via http://mcm.leeds.ac.uk/ MCM;

2. FGs that are measured or measurable (i.e., have absorption bands) for FTIR analysis (Pavia et al., 2008);

3. molecular fragments used by SIMPOL.1 for estimation of pure organic compound vapor pressures;

4. bonds used for calculation of carbon oxidation state $\left(\overline{\mathrm{OS}}_{\mathrm{C}}\right)$ (Kroll et al., 2011, 2015).

As there are several ways to define SMARTS patterns for substructure matching, we prescribe a general method for formulating patterns in such a way that permits a user to not only match and test the total number of FGs within a molecule but also confirm that all atoms within molecule are classified uniquely into a set of FGs (except polyfunctional carbon, which can be associated with many FGs). We present a validation test for the groups defined, and show example applications for mapping molecules onto two-dimensional volatility basis set (2-D VBS) space, inter-measurement comparison between OM composition reported by GC-MS and FTIR for several source classes, and discuss implications for further applications. The patterns and software written for this manuscript are provided in a version-controlled repository (Appendix A).

\section{Methods}

In this section, we present a series of patterns corresponding to substructures useful for vapor pressure estimation of FGs in molecules defined by measurements and chemical mechanisms (Sect. 2.1) as well as the methods and compound sets used for their validation (Sect. 2.2). We further describe the data set used for constructing a few example applications (Sect. 2.3).

\subsection{Pattern specification for matching substructures}

Four groups of patterns are defined: the first group (Table 1, substructures 1-33) corresponds to the complete set of FGs that can be found in the MCMv3.2 $\alpha$-pinene and 1,3,5trimethylbenzene oxidation scheme (Jenkin et al., 1997; Saunders et al., 2003), the second group is used to study the FG abundance associated with FTIR measurements (FGs not specified before, containing carbon, oxygen, and nitrogen atoms; Table 1, substructures 33-57), the third group corresponds to the FGs used to build the SIMPOL.1 model (Pankow and Asher, 2008) to predict pure-component vapor pressures that are not present in the first set of patterns (Table 2), and the fourth group is used to calculate the oxidation state of carbon atoms (Table 3). The regions of absorption in the IR spectrum associated with FGs patterns are reported in Table 4 as an additional reference. The OpenBabel toolkit (O'Boyle et al., 2011) is called through the Pybel library (O'Boyle et al., 2008) in Python to search and enumerate abundances of fragments (most of which are specified by SMARTS) in each molecule (specified by SMILES). A few groups for which SMARTS patterns were difficult to obtain were calculated through algebraic relations specified through the string formatting syntax of the Python programming language. In this syntax, values pre-computed through SMARTS matching are combined together to estimate properties for another group. While SMARTS can also describe ring definitions, ring perception is a difficult task partly due to the varying definitions of a ring, which must consider definition of aromaticity (tautomerism must also be considered) 
Table 1. Substructures matched in order to account for the complete set of carbons and oxygen atoms in the set of compounds constituting the $\alpha$-pinene and 1,3,5-trimethylbenzene degradation scheme in MCM v3.2 (substructures 1-33) and extra molecular substructures measurable with FTIR (substructures 33-57). For space constraints the SMARTS patterns have been reported on multiple lines, even if the SMARTS notation requires unique lines.

\begin{tabular}{|c|c|c|c|c|}
\hline No. & Substructure & Definition & Chemoinformatic definition & Matched pattern \\
\hline 1 & $\begin{array}{l}\text { Quaternary } \\
\text { carbon }\end{array}$ & $\begin{array}{l}\text { A carbon atom bonded to four } \\
\text { carbon atoms. }^{\text {a }}\end{array}$ & {$[\$([C]([\# 6])([\# 6])([\# 6])[\# 6])]$} & \\
\hline 2 & Alkane $\mathrm{CH}$ & $\begin{array}{l}\text { Hydrogen atom attached to } \\
\text { an } \mathrm{sp}^{3} \text { carbon atom. }\end{array}$ & {$[\mathrm{CX} 4][\mathrm{H}]$} & \\
\hline 3 & Alkene $\mathrm{CH}$ & $\begin{array}{l}\text { Hydrogen atom attached to a } \\
\text { non- aromatic } \mathrm{sp}^{2} \text { carbon atom. }\end{array}$ & {$[\mathrm{CX} 3 ; \$(\mathrm{C}=\mathrm{C})][\mathrm{H}]$} & \\
\hline 4 & Aromatic $\mathrm{CH}$ & $\begin{array}{l}\text { Hydrogen atom attached to an } \\
\text { aromatic } \mathrm{sp}^{2} \text { carbon atom. }\end{array}$ & {$[\mathrm{C}][\mathrm{H}]$} & \\
\hline 5 & 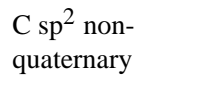 & $\begin{array}{l}\text { A non-aromatic } \mathrm{sp}^{2} \text { carbon } \\
\text { atom bonded to three carbons. }\end{array}$ & {$[\mathrm{CX} 3 ; \$([\mathrm{C}]([\# 6])(=[\# 6])[\mathrm{C}])]$} & \\
\hline 6 & $\begin{array}{l}\mathrm{C} \mathrm{sp}{ }^{2} \text { aromatic } \\
\text { non-quaternary }\end{array}$ & $\begin{array}{l}\text { An aromatic } \mathrm{sp}^{2} \text { carbon atom } \\
\text { bonded to three carbon atoms. }\end{array}$ & {$[c ; \$([c](c)(c)[C])]$} & \\
\hline 7 & Alcohol OH & $\begin{array}{l}\text { A compound containing an } \\
-\mathrm{OH} \text { (hydroxyl) group bonded } \\
\text { to a tetrahedral carbon atom. }\end{array}$ & {$[\mathrm{C} ; ! \$(\mathrm{C}=\mathrm{O})][\mathrm{OX} 2 \mathrm{H}][\mathrm{H}]$} & \\
\hline 8 & Ketone & $\begin{array}{l}\text { A compound containing a } \\
\text { carbonyl group bonded to } \\
\text { two carbon atoms. }{ }^{\text {a }}\end{array}$ & $\begin{array}{l}{[\mathrm{CX} 3 ; \$(\mathrm{C}([\# 6])(=[0])[\# 6])]} \\
(=[0 ; ! \$([0][0])]))\end{array}$ & \\
\hline 9 & Aldehyde & $\begin{array}{l}\text { A compound containing a } \\
-\mathrm{CHO} \text { group (excludes formaldehyde). }{ }^{\mathrm{a}}\end{array}$ & $\begin{array}{l}{[\mathrm{CX} 3 ; \$(\mathrm{C}([\# 1])(=[\mathrm{O}])[\# 6])]} \\
(=[0 ; ! \$([\mathrm{O}][\mathrm{O}])])[\mathrm{H}]\end{array}$ & \\
\hline 10 & Carboxylic acid & $\begin{array}{l}\text { A compound containing a carboxyl, } \\
-\mathrm{COOH} \text {, group (excludes formic acid). }\end{array}$ & $\begin{array}{l}{[\mathrm{CX} 3 ; ! \$([\mathrm{CX} 3][\mathrm{H}])](=\mathrm{O})} \\
{[\mathrm{OX} 2 \mathrm{H}][\mathrm{H}]}\end{array}$ & \\
\hline 11 & Formic acid & Formic acid compound. & {$[\mathrm{CX} 3](=\mathrm{O})([\mathrm{H}])[\mathrm{OX} 2 \mathrm{H}][\mathrm{H}]$} & \\
\hline 12 & Acyloxy radical & $\begin{array}{l}\text { Oxygen-centered radicals consisting of } \\
\text { an acyl radical bonded to an oxygen atom. }\end{array}$ & $\begin{array}{l}{[\mathrm{C} ; \$(\mathrm{C}=\mathrm{O})](=\mathrm{O})[\mathrm{OX} 2 ;} \\
! \$([\mathrm{OX} 2][\mathrm{H}]) ; ! \$([\mathrm{OX} 2][\mathrm{O}]) ; \\
! \$([\mathrm{OX} 2][\mathrm{N}]) ; ! \$([\mathrm{OX} 2]([\# 6]) \\
[\# 6])]\end{array}$ & \\
\hline
\end{tabular}


Table 1. Continued.

\begin{tabular}{|c|c|c|c|c|}
\hline No. & Substructure & Definition & Chemoinformatic definition & Matched pattern \\
\hline 13 & Ester & $\begin{array}{l}\text { A derivative of a carboxylic acid in which } \\
\mathrm{H} \text { of the carboxyl group is replaced } \\
\text { by a carbon. }{ }^{\mathrm{a}}\end{array}$ & $\begin{array}{l}{[\mathrm{CX} 3 \mathrm{H} 1, \mathrm{CX} 3](=\mathrm{O})} \\
{[\mathrm{OX} 2 \mathrm{HO}][\# 6 ; ! \$([\mathrm{C}]=[\mathrm{O}])]}\end{array}$ & \\
\hline 14 & Ether & An -OR group, where $\mathrm{R}$ is an alkyl group. ${ }^{\mathrm{a}}$ & $\begin{array}{l}{[\mathrm{OD} 2]([\# 6 ; ! \$(C=0)])} \\
{[\# 6 ; ! \$(C=0)]}\end{array}$ & \\
\hline 15 & Formaldehyde & Formaldehyde compound. & $\begin{array}{l}{[\mathrm{CX} 3 ; \$(\mathrm{C}(=[\mathrm{O}])([\# 1])[\# 1])]} \\
(=[0 ; ! \$([\mathrm{O}][\mathrm{O}])])([\mathrm{H}])[\mathrm{H}]\end{array}$ & \\
\hline 16 & Phenol OH & $\begin{array}{l}\text { Compounds having one or more hydroxy } \\
\text { groups attached to a benzene or other } \\
\text { arene ring. }\end{array}$ & {$[\mathrm{C} ; ! \$(\mathrm{C}=\mathrm{O})][\mathrm{OX} 2 \mathrm{H}][\mathrm{H}]$} & \\
\hline 17 & Oxy radical (alkoxy) & $\begin{array}{l}\text { Oxygen-centered radical consisting of } \\
\text { an oxygen bonded to an alkyl. }\end{array}$ & 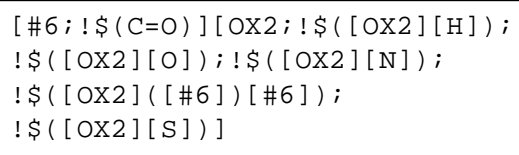 & \\
\hline 18 & $\begin{array}{l}\text { Carboxylic amide } \\
\text { (primary, secondary } \\
\text { and tertiary) }\end{array}$ & $\begin{array}{l}\text { A derivative of a carboxylic acid in which } \\
\text { the -OH is replaced by an amine. }{ }^{\text {a }}\end{array}$ & $\begin{array}{l}{[\mathrm{CX} 3](=0)[\mathrm{NX} 3 ; ! \$(\mathrm{~N}=0)]} \\
([\# 6, \# 1])[\# 6, \# 1]\end{array}$ & $\stackrel{1}{\mathrm{C}}(\mathrm{H})$ \\
\hline 19 & Peroxide & $\begin{array}{l}\text { Compounds of structure ROOR in which } \\
\text { R may be any organyl group. }\end{array}$ & [\#6] [OD2] [OD2, OD1] [\#6] & \\
\hline 20 & Peroxy radical & $\begin{array}{l}\text { Oxygen-centered radical derived from } \\
\text { an hydroperoxide. }\end{array}$ & $\begin{array}{l}{[\mathrm{O} ; ! \$([\mathrm{O}][\# 6]) ; ! \$([\mathrm{O}][\mathrm{H}]) ;} \\
! \$([\mathrm{OX} 2][\mathrm{N}]) ; ! \$(\mathrm{O}=\mathrm{C})][\mathrm{O}] \\
{[\# 6 ; ! \$([\mathrm{C}](=\mathrm{O}) \sim \mathrm{OO})]}\end{array}$ & \\
\hline 21 & $\mathrm{C}=\mathrm{O}^{+}-\mathrm{O}^{-}$group & Group of the type $\mathrm{C}=\mathrm{O}^{+}-\mathrm{O}^{-}$ & $\begin{array}{l}{[0 ; ! \$([\mathrm{O}][\# 6]) ; ! \$([\mathrm{O}][\mathrm{H}]) ;} \\
! \$([\mathrm{OX} 2][\mathrm{N}]) ; ! \$(\mathrm{O}=\mathrm{C})] \\
{[\mathrm{O}]=[\# 6 ; !([\mathrm{C}](=\mathrm{O}) \sim \mathrm{OO})]} \\
([\# 6, \# 1])[\# 6, \# 1]\end{array}$ & \\
\hline 22 & C-nitro & $\begin{array}{l}\text { Compounds having the nitrogroup, } \\
-\mathrm{NO}_{2} \text { (free valence on nitrogen), } \\
\text { which is attached to a carbon. }{ }^{\mathrm{b}}\end{array}$ & $\begin{array}{l}{[\# 6][\$([N X 3](=0)=0)} \\
\$([N X 3+](=0)[O-])](\sim[O]) \\
(\sim[0])\end{array}$ & $C(A r)-N_{O}^{\prime \prime}$ \\
\hline 23 & Organonitrate & $\begin{array}{l}\text { Compounds having the nitrogroup, } \\
-\mathrm{NO}_{2} \text { (free valence on nitrogen), } \\
\text { which is attached to an oxygen. }\end{array}$ & $\begin{array}{l}{[\# 6][0][\$([\mathrm{NX} 3](=[\mathrm{OX} 1])} \\
(=[\mathrm{OX} 1]) 0), \$([\mathrm{NX} 3+]([\mathrm{OX} 1-]) \\
(=[\mathrm{OX} 1]) 0)](\sim[0])(\sim[0])\end{array}$ & "O \\
\hline 24 & Peroxyacyl nitrate & $\begin{array}{l}\text { Functional group containing } \\
\text { a }-\mathrm{COOONO}_{2} \text {. }\end{array}$ & {$[\mathrm{C}](=\mathrm{O}) \mathrm{OO}[\mathrm{N}](\sim \mathrm{O}) \sim[\mathrm{O}]$} & \\
\hline 25 & Peroxy acid & $\begin{array}{l}\text { Acids in which an acidic }-\mathrm{OH} \text { group } \\
\text { has been replaced by an }-\mathrm{OOH} \text { group. }\end{array}$ & $\mathrm{C}(=\mathrm{O}) \mathrm{O}[\mathrm{O}][\mathrm{H}]$ & \\
\hline
\end{tabular}


Table 1. Continued.

\begin{tabular}{|c|c|c|c|c|}
\hline No. & Substructure & Definition & Chemoinformatic definition & Matched pattern \\
\hline 26 & Acylperoxy radical & $\begin{array}{l}\text { Oxygen-centered radical } \\
\text { derived from a peroxy acid. }\end{array}$ & $\begin{array}{l}\mathrm{C}(=\mathrm{O}) \mathrm{O}[\mathrm{O} ; ! \text { \$ }([\mathrm{O}][\mathrm{H}]) ; \\
! \$([\mathrm{OX} 2][\mathrm{N}])]\end{array}$ & \\
\hline 27 & Organosulfate & $\begin{array}{l}\text { Esters compounds derived } \\
\text { from alcohol and sulfuric acids } \\
\text { functional groups. }\end{array}$ & $\begin{array}{l}{[\# 6][0][\operatorname{SX} 4 ;} \\
\$([\operatorname{SX} 4](=0)(=0)(0) 0) \\
\$([\operatorname{SX} 4+2]([0-])([0-])(0) 0)] \\
(\sim[0])(\sim[0])(\sim[0])\end{array}$ & - \\
\hline 28 & Hydroperoxide & $\begin{array}{l}\text { A compound containing an } \\
\text {-OOH group. }{ }^{\text {a }}\end{array}$ & $\begin{array}{l}{[\# 6 ; ! \$(\mathrm{C}=\mathrm{O})][\mathrm{OD} 2]} \\
{[\mathrm{OX} 2 \mathrm{H}, \mathrm{OD} 1][\# 1]}\end{array}$ & \\
\hline 29 & Primary amine & $\begin{array}{l}\text { An amine in which nitrogen is } \\
\text { bonded to one carbon and two } \\
\text { hydrogens. }\end{array}$ & $\begin{array}{l}{[\# 6][N X 3 ; H 2 ; ! \$(N C=O)]} \\
([H])[H]\end{array}$ & \\
\hline 30 & Secondary amine & $\begin{array}{l}\text { An amine in which nitrogen is } \\
\text { bonded to two carbons and } \\
\text { one hydrogen. }{ }^{\text {a }}\end{array}$ & $\begin{array}{l}{[\# 6][N X 3 ; H ; ! \$(N C=O)]} \\
([\# 6])[\mathrm{H}]\end{array}$ & \\
\hline 31 & Tertiary amine & $\begin{array}{l}\text { An amine in which nitrogen is } \\
\text { bonded to three carbons. }^{\text {a }}\end{array}$ & $\begin{array}{l}{[\# 6][N X 3 ; H 0 ; ! \$(N C=O) ;} \\
! \$(N=O)]([\# 6])[\# 6]\end{array}$ & \\
\hline 32 & Peroxy nitrate & $\begin{array}{l}\text { Functional group containing } \\
\text { a } \mathrm{COONO}_{2} \text {. }\end{array}$ & $\begin{array}{l}{[\# 6][0 ; ! \$(\mathrm{OOC}(=\mathrm{O}))]} \\
{[0 ; ! \$(\mathrm{OOC}(=\mathrm{O}))][\mathrm{N}](\sim 0) \sim[\mathrm{O}]}\end{array}$ & \\
\hline 33 & Anhydride & $\begin{array}{l}\text { Two acyl groups bonded to an } \\
\text { oxygen atom. }^{\text {a }}\end{array}$ & {$[\mathrm{CX} 3](=0)[0][\mathrm{CX} 3](=0)$} & $\mathrm{O}$ \\
\hline 34 & $\begin{array}{l}\text { Alcohol O-H and } \\
\text { Phenol O-H }\end{array}$ & Alcohol and phenol O-H. & $\begin{array}{l}{[\mathrm{OX} 2 \mathrm{H} ; \text { \$ }([\mathrm{O}]([\# 6])[\mathrm{H}]) ;} \\
! \$([\mathrm{O}](\mathrm{C}=\mathrm{O})[\mathrm{H}])][\mathrm{H}]\end{array}$ & \\
\hline 35 & Alkane $\mathrm{C}-\mathrm{H}$ in $-\mathrm{CH}_{3}$ & $\mathrm{C}-\mathrm{H}$ bonds in $\mathrm{CH}_{3}$ group. & {$[\mathrm{CX} 4 ; \$(\mathrm{C}([\mathrm{H}])([\mathrm{H}])[\mathrm{H}])][\mathrm{H}]$} & \\
\hline 36 & Alkane $\mathrm{C}-\mathrm{H}$ in $-\mathrm{CH}_{2}$ & $\mathrm{C}-\mathrm{H}$ bonds in $\mathrm{CH}_{2}$ group. & $\begin{array}{l}{[\mathrm{CX} 4 ; \$(\mathrm{C}([\mathrm{H}])([\mathrm{H}])} \\
([! \# 1])[! \# 1])][\mathrm{H}]\end{array}$ & \\
\hline 37 & Alkynes C-H & $\begin{array}{l}\text { Hydrogen bonded to an sp carbon } \\
\text { in an alkyne group. }\end{array}$ & {$[\mathrm{C} ; \$(\mathrm{C \# C})][\mathrm{H}]$} & $-\mathrm{H}$ \\
\hline 38 & Alkynes $\mathrm{C} \equiv \mathrm{C}$ & $\begin{array}{l}\text { Two carbons that are triple } \\
\text { bonded. }\end{array}$ & {$[\mathrm{C}] \#[\mathrm{C}]$} & $-\mathrm{C} \equiv \mathrm{C}-$ \\
\hline 39 & Aromatic $\mathrm{C}=\mathrm{C}$ & $\begin{array}{l}\text { Two aromatic carbons bonded } \\
\text { with an aromatic bond. }\end{array}$ & $\mathrm{C}: \mathrm{C}$ & \\
\hline
\end{tabular}


Table 1. Continued.

\begin{tabular}{|c|c|c|c|c|}
\hline No. & Substructure & Definition & Chemoinformatic definition & Matched pattern \\
\hline 40 & $\begin{array}{l}\text { Conjugated aldehyde } \\
\mathrm{C}=\mathrm{O} \text { and } \alpha, \beta \mathrm{C}=\mathrm{C}\end{array}$ & $\begin{array}{l}\text { An aldehyde } \mathrm{C}=\mathrm{O} \text { conjugated with } \\
\text { an alkene } \mathrm{C}=\mathrm{C} \text { in } \alpha \text { and } \beta \\
\text { positions. }\end{array}$ & $\begin{array}{l}{[\mathrm{CX} 3 ; \$(\mathrm{C}(=[\mathrm{O}])([\# 1])[\mathrm{C}]=[\mathrm{C}])]} \\
([\mathrm{C}]=[\mathrm{C} ; ! \$(\mathrm{CC})]) \\
(=[\mathrm{O} ; ! \$([\mathrm{O}][\mathrm{O}])])[\mathrm{H}]\end{array}$ & CO \\
\hline 41 & $\begin{array}{l}\text { Conjugated aldehyde } \\
\mathrm{C}=\mathrm{O} \text { and phenyl }\end{array}$ & $\begin{array}{l}\text { An aldehyde } \mathrm{C}=\mathrm{O} \text { conjugated } \\
\text { with a phenyl group. }\end{array}$ & $\begin{array}{l}{[\mathrm{CX} 3 ; \$(\mathrm{C}(=[0])([\# 1])} \\
[\mathrm{c} ; \$(\mathrm{c} 1 \mathrm{cc}[\mathrm{C}] \mathrm{cc} 1)])]([\# 6, \# 1]) \\
(=[0 ; ! \$([0][0])])[\mathrm{H}]\end{array}$ & $\begin{array}{l}-\mathrm{C}-\mathrm{H} \\
\mathrm{O} \\
\mathrm{O}\end{array}$ \\
\hline 42 & $\begin{array}{l}\text { Conjugated aldehyde } \\
\mathrm{C}=\mathrm{O} \text { and } \alpha, \beta \mathrm{C}=\mathrm{C} \\
\text { and phenyl }\end{array}$ & $\begin{array}{l}\text { An aldehyde } \mathrm{C}=\mathrm{O} \text { conjugated with } \\
\text { alkene } \mathrm{C}=\mathrm{C} \text { in } \alpha \text { and } \beta \\
\text { positions and a phenyl group. }\end{array}$ & $\begin{array}{l}{[\mathrm{CX} 3 ; \$(\mathrm{C}(=[\mathrm{O}])([\# 1])[\mathrm{C}]=[\mathrm{C}]} \\
[\mathrm{C} ; \$(\mathrm{C} 1 \mathrm{CC}[\mathrm{C}] \mathrm{CC} 1)])] \\
([\mathrm{C}])(=[\mathrm{O} ; ! \$([\mathrm{O}][\mathrm{O}])])[\mathrm{H}]\end{array}$ & $\begin{array}{l}-\mathrm{C}-\mathrm{H} \\
\mathrm{O}\end{array}$ \\
\hline 43 & $\begin{array}{l}\text { Conjugated ketone } \\
\mathrm{C}=\mathrm{O} \text { and } \alpha, \alpha \mathrm{C}=\mathrm{C}\end{array}$ & $\begin{array}{l}\text { A ketone } \mathrm{C}=\mathrm{O} \text { conjugated with an } \\
\text { alkene } \mathrm{C}=\mathrm{C} \text { in } \alpha \text { and } \beta \text { positions. }\end{array}$ & $\begin{array}{l}{[\mathrm{CX} 3 ; \$(\mathrm{C}([\# 6])(=[\mathrm{O}])} \\
[\mathrm{C}]=[\mathrm{C}])]([\mathrm{C}]) \\
(=[\mathrm{O} ; ! \$([\mathrm{O}][\mathrm{O}])])[\mathrm{C}]\end{array}$ & cis \\
\hline 44 & $\begin{array}{l}\text { Conjugated ketone } \\
\mathrm{C}=\mathrm{O} \text { and phenyl }\end{array}$ & $\begin{array}{l}\text { A ketone } \mathrm{C}=\mathrm{O} \text { conjugated with a } \\
\text { phenyl group. }\end{array}$ & $\begin{array}{l}{[\mathrm{CX} 3 ; \$(\mathrm{C}([\mathrm{C}])(=[\mathrm{O}])} \\
[\mathrm{C} ; \$(\mathrm{c} 1 \mathrm{CC}[\mathrm{C}] \mathrm{CC} 1)])]([\mathrm{C}]) \\
(=[0 ; ! \$([O][O])])[\mathrm{C}]\end{array}$ & $\begin{array}{l}-\mathrm{C}-\mathrm{C} \\
\mathrm{O}\end{array}$ \\
\hline 45 & $\begin{array}{l}\text { Conjugated ketone } \\
\mathrm{C}=\mathrm{O} \text { and two phenyl }\end{array}$ & $\begin{array}{l}\text { A ketone } \mathrm{C}=\mathrm{O} \text { conjugated with two } \\
\text { phenyl groups. }\end{array}$ & $\begin{array}{l}{[\mathrm{CX} 3 ; \$(\mathrm{C}([\mathrm{C}, \$(\mathrm{clcc}[\mathrm{C}] \mathrm{CC} 1)])} \\
(=[\mathrm{O}])[\mathrm{c} ; \$(\mathrm{c} 1 \mathrm{cc}[\mathrm{c}] \mathrm{Cc} 1)])] \\
([\mathrm{c}])(=[0 ; ! \$([\mathrm{O}][\mathrm{O}])])[\mathrm{c}]\end{array}$ & Ar-C \\
\hline 46 & $\begin{array}{l}\text { Conjugated ester } \\
\mathrm{C}=\mathrm{O} \text { and } \alpha, \beta \mathrm{C}=\mathrm{C}\end{array}$ & $\begin{array}{l}\text { An ester } \mathrm{C}=\mathrm{O} \text { conjugated with alkene } \\
\mathrm{C}=\mathrm{C} \text { in } \alpha \text { and } \beta \text { positions. }\end{array}$ & $\begin{array}{l}{[\mathrm{C} ; ! \$(\mathrm{CC})]=[\mathrm{C}]} \\
{[\mathrm{CX} 3 ; \$([\mathrm{C}]([\mathrm{O}][\mathrm{C}])} \\
(=[\mathrm{O}])[\mathrm{C}]=[\mathrm{C}])]([\mathrm{O}][\mathrm{C}]) \\
(=[\mathrm{O} ; !([\mathrm{O}][\mathrm{O}])])\end{array}$ & \\
\hline 47 & $\begin{array}{l}\text { Conjugated ester } \\
\mathrm{C}=\mathrm{O} \text { and phenyl }\end{array}$ & $\begin{array}{l}\text { A ester } \mathrm{C}=\mathrm{O} \text { conjugated with a phenyl } \\
\text { group. }\end{array}$ & $\begin{array}{l}{[\mathrm{CX} 3 ; \$([\mathrm{C}]([\mathrm{O}][\mathrm{C}])(=[\mathrm{O}])} \\
[\mathrm{C}, \$(\mathrm{C} 1 \mathrm{cc}[\mathrm{C}] \mathrm{CC} 1)])]([\mathrm{O}][\mathrm{C}]) \\
(=[\mathrm{O} ; \$([\mathrm{O}][\mathrm{O}])])\end{array}$ & $\begin{array}{c}\mathrm{Ar}-\mathrm{C}-\mathrm{O}-\mathrm{C} \\
\mathrm{O}\end{array}$ \\
\hline 48 & $\begin{array}{l}\text { Conjugated ester } \\
\mathrm{C}-\mathrm{O} \text { with } \mathrm{C}=\mathrm{C} \\
\text { or phenyl }\end{array}$ & $\begin{array}{l}\text { An ester } \mathrm{C}=\mathrm{O} \text { conjugated with alkene } \\
\mathrm{C}=\mathrm{C} \text { in } \alpha \text { and } \beta \text { positions and a } \\
\text { phenyl group. }\end{array}$ & $\begin{array}{l}{[\mathrm{CX} 3 ; \$([\mathrm{C}]([\# 6])(=[\mathrm{O}])[\mathrm{O}]} \\
[\mathrm{C}]=[\mathrm{C}]), \$([\mathrm{C}]([\# 6])(=[\mathrm{O}]) \\
[\mathrm{O}][\mathrm{C} ; \$(\mathrm{ClcC}[\mathrm{C}] \mathrm{CC} 1)])] \\
(=[0 ; ! \$([\mathrm{O}][\mathrm{O}])])[\mathrm{O}] \\
{[\# 6 ; \$(\mathrm{C}=\mathrm{C}), \$(\mathrm{C} 1 \mathrm{CC}[\mathrm{C}] \mathrm{CC} 1)]}\end{array}$ & $\begin{array}{l}\text { I' } \\
-C_{C}^{\prime} \\
\text { and } \\
-A r\end{array}$ \\
\hline 49 & Nonacid carbonyl & $\begin{array}{l}\text { Carbonyl group in ketones and } \\
\text { aldehydes. }\end{array}$ & $\begin{array}{l}{[\mathrm{CX} 3 ; \$(\mathrm{C}([\# 6, \# 1])(=[0])} \\
[\# 6, \# 1])](=[0 ; ! \$([0][0])])\end{array}$ & \\
\hline 50 & Acyl chloride & $\begin{array}{l}\text { An acyl group bonded to a chloride } \\
\text { atom. }\end{array}$ & $\begin{array}{l}{[\mathrm{C}, \$([\mathrm{C}]([\# 6])(=[\mathrm{O}]))]} \\
(=\mathrm{O})[\mathrm{Cl}]\end{array}$ & \\
\hline 51 & Isocyanate & $\mathrm{An}-\mathrm{N}=\mathrm{C}=\mathrm{O}$ group. & $\begin{array}{l}{[N ; \$([N]([\# 6])=[C]=[O])]} \\
=[C]=[O]\end{array}$ & 1 \\
\hline 52 & Isothiocyanate & $\mathrm{An}-\mathrm{N}=\mathrm{C}=\mathrm{S}$ group. & $\begin{array}{l}{[N ; \$([N]([\# 6])=[C]=[S])]} \\
=[C]=[S]\end{array}$ & \\
\hline
\end{tabular}


Table 1. Continued.

\begin{tabular}{|c|c|c|c|c|}
\hline No. & Substructure & Definition & Chemoinformatic definition & Matched pattern \\
\hline 53 & Imine & A carbon-nitrogen double bond, $\mathrm{R}_{2} \mathrm{C}=\mathrm{NR}$. & $\begin{array}{l}{[C ; \$(C([\# 6, \# 1])([\# 6, \# 1])=[N])]} \\
=[N][\# 1, \# 6]\end{array}$ & $\mathrm{C}(\mathrm{H})$ \\
\hline 54 & Oxime & A carbon-nitrogen double bond, $\mathrm{R}_{2} \mathrm{C}=\mathrm{NOH}$. & $\begin{array}{l}{[C ; \$(C([\# 6, \# 1])([\# 6, \# 1])} \\
=[\mathrm{N}][\mathrm{O}][\mathrm{H}])]=[\mathrm{N}][\mathrm{O}][\mathrm{H}]\end{array}$ & \\
\hline 55 & Aliphatic nitro & $\begin{array}{l}\text { Compounds having the nitro group, }-\mathrm{NO}_{2} \\
\text { (free valence on nitrogen), which is } \\
\text { attached to an aliphatic carbon. }\end{array}$ & $\begin{array}{l}{[C][\$([N X 3](=0)=0),} \\
\$([N X 3+](=0)[O-])] \\
(\sim[0])(\sim[0])\end{array}$ & \\
\hline 56 & Aromatic nitro & $\begin{array}{l}\text { Compounds having the nitro group, }-\mathrm{NO}_{2} \\
\text { (free valence on nitrogen), which is } \\
\text { attached to an aromatic carbon. }\end{array}$ & $\begin{array}{l}{[\mathrm{c}][\$([\mathrm{NX} 3](=\mathrm{O})=0)} \\
\$([\mathrm{NX} 3+](=0)[\mathrm{O}-])] \\
(\sim[\mathrm{O}])(\sim[\mathrm{O}])\end{array}$ & $\operatorname{Ar}-N_{1}^{\prime \prime}$ \\
\hline 57 & Nitrile & $\begin{array}{l}\text { A carbon atom bonded to a nitrogen } \\
\text { atom with a triple bond. }\end{array}$ & {$[\mathrm{C} ; \$([\mathrm{C}] \#[\mathrm{~N}])] \#[\mathrm{~N}]$} & \\
\hline
\end{tabular}

${ }^{a}$ Brown et al. (2012). ${ }^{b}$ Miloslav et al. (2015).

(Berger et al., 2004; May and Steinbeck, 2014). In this work, we use the smallest set of smallest rings (SSSR) (Downs et al., 1989) as defined by OpenBabel and many chemoinformatic software packages to enumerate the number of aromatic rings in this work. Ring enumeration is the only task specific to the software implementation, but otherwise the patterns specified can be ported to other software packages. The full implementation of patterns and scripts described in this manuscript are made available through an online repository (Appendix A).

We adapt chemoinformatic tools for use with SIMPOL.1 partly because the portable SMARTS pattern approach is more readily compatible with this model parameterization. We note that EVAPORATION vapor pressure model is fitted to more recent diacid measurements and includes positional information and nonlinear interactions among FGs (Compernolle et al., 2011). Positional arguments can be included by querying specific structural information from the internal representations of molecular graphs according to implementations in various software packages, or by formulating SMARTS patterns which require specificity in the arrangement of neighboring atoms (Barley et al., 2011; Topping et al., 2016). In this work, positional information of FGs are used only for conjugated aldehyde, ketone, and ester with an alkene or benzene ring (Table 1, substructures 40-48). With regards to the use of SIMPOL.1, vapor pressure predictions can also be improved by updating coefficients for the model with new estimates (Yeh and Ziemann, 2015).

SMARTS patterns for tallying the number of FGs can be formulated in many ways. Therefore, we provide an exam- ple for the aldehyde FG group to illustrate the development process, with particular attention paid to the description of atoms returned in the matched set and how their bonding environments are defined. We first describe a formulation specific for fulfilling the atom-level validation which requires two patterns to account for all aldehyde groups in the system, as well as an alternate formulation for only enumerating FGs that requires only a single pattern.

When applied to propionaldehyde, the set of atoms returned by matching the pattern for substructure 9 in Table 1 will be 3,4 , and 10 (as labeled in Fig. 1a). The first bracket $[\mathrm{CX} 3 ;$; $(\mathrm{C}([\# 1])(=[0])[\# 6])]$ describes the carbon atom to be matched and returned. $\mathrm{CX} 3$ describes a carbon with three bonds (effectively $\mathrm{sp}^{2}$ ); $\$(C([\# 1])(=[0])[\# 6])$ qualifies that it is bonded to hydrogen, oxygen, and another carbon. The expression $(=[0 ; ! \$([0][0])])$ describes the double-bonded oxygen to this carbon atom; ! $([\mathrm{O}][\mathrm{O}])]$ excludes preventing matching of $\mathrm{C}=\mathrm{O}^{+}-\mathrm{O}^{-}$(defined as a separate group, substructure 21 in Table 1) that are present in other molecules (an example is provided in Fig. 1b). The last bracket $[\mathrm{H}]$ is included to explicitly include the hydrogen atom in the returned set. While the $\mathrm{sp}^{3}$ carbon attached to the $\mathrm{sp}^{2}$ is not returned in the set of matched atoms, this additional specificity is necessary to prevent double counting of the same aldehydic group in the formaldehyde molecule, which contains two hydrogen atoms bonded to $\mathrm{sp}^{2}$ carbon. A separate SMARTS pattern is defined for formaldehyde (Table 1, substructure 15). (For similar reasons, a SMARTS pattern spe- 
Table 2. Chemical substructures required by SIMPOL.1 model (Pankow and Asher, 2008). The column denoted by $k$ corresponds to the group number of Pankow and Asher (2008), Table 5. For the calculation of the ester (SIMPOL.1), the generic ester specified in Table 1 (substructure 13) is specified. The group named "Carbon number on the OH side of an amide" is used in the calculation of the "Carbon number on the acid side of an amide" but is not present in the SIMPOL.1 groups indicated by Pankow and Asher (2008).

\begin{tabular}{|c|c|c|}
\hline Groups & Chemoinformatic definition or reference to Table 1 & $k$ \\
\hline Carbon number & [\#6 ] & 1 \\
\hline $\begin{array}{l}\text { Carbon number on the acid side } \\
\text { of an amide }\end{array}$ & $\begin{array}{l}\{\text { Carbon number }\}- \\
\text { Carbon number on the oH side of an amide }\}-1 \\
\text { if (\{Amide, primary }\}+\{\text { Amide, secondary }\} \\
+\{\text { Amide, tertiary }\} 0) \\
\text { else } 0\end{array}$ & 2 \\
\hline Aromatic ring ${ }^{\mathrm{c}}$ & count_aromatic_rings (molecule) & 3 \\
\hline Non-aromatic ring ${ }^{\mathrm{c}}$ & count_nonaromatic_rings (molecule) & 4 \\
\hline $\mathrm{C}=\mathrm{C}$ (non-aromatic) & $\mathrm{C}=\mathrm{C}$ & 5 \\
\hline $\begin{array}{l}\mathrm{C}=\mathrm{C}-\mathrm{C}=\mathrm{O} \text { in non-aromatic } \\
\text { ring }\end{array}$ & {$[\$(C=C C=O) ; A ; R]$} & 6 \\
\hline Hydroxyl (alkyl) & Table 1 , number 7 & 7 \\
\hline Aldehyde & {$[\mathrm{CX} 3 ; \$(\mathrm{C}([\# 1])(=[0])[\# 6, \# 1])](=[0 ; ! \$([0][0])])$} & 8 \\
\hline Ketone & Table 1 , number 8 & 9 \\
\hline Carboxylic acid & {$[\mathrm{CX} 3](=\mathrm{O})[\mathrm{OX} 2 \mathrm{H}][\mathrm{H}]$} & 10 \\
\hline Ester (SIMPOL.1) ${ }^{b}$ & $\{$ Ester $\}-\{$ Nitroester $\}$ & 11 \\
\hline Ether (SIMPOL.1) & {$[\mathrm{OD} 2]([\mathrm{C} ; ! \mathrm{R} ; !$ ! $(\mathrm{C}=\mathrm{O})])[\mathrm{C} ; ! \mathrm{R} ; ! \$(\mathrm{C}=\mathrm{O})]$} & 12 \\
\hline Ether, alicyclic & {$[\mathrm{OD} 2 ; \mathrm{R}]([\mathrm{C} ; ! \$(\mathrm{C}=\mathrm{O}) ; \mathrm{R}])[\mathrm{C} ; ! \$(\mathrm{C}=\mathrm{O}) ; \mathrm{R}]$} & 13 \\
\hline Ether, aromatic & $\mathrm{C} \sim[0,0] \sim[\mathrm{C}, \mathrm{C} \& ! \$(\mathrm{C}=0)]$ & 14 \\
\hline Nitrate & Table 1 , number 23 & 15 \\
\hline Nitro & Table 1, number 22 & 16 \\
\hline $\begin{array}{l}\text { Aromatic hydroxyl (e.g., phe- } \\
\text { nol) }\end{array}$ & Table 1 , number 16 & 17 \\
\hline Amine, primary & {$[\mathrm{C}][\mathrm{NX} 3 ; \mathrm{H} 2 ; ! \$(\mathrm{NC}=\mathrm{O})]([\mathrm{H}])[\mathrm{H}]$} & 18 \\
\hline Amine, secondary & {$[\mathrm{C}][\mathrm{NX} 3 ; \mathrm{H} ; !$ \$ $(\mathrm{NC}=\mathrm{O})]([\mathrm{C}])[\mathrm{H}]$} & 19 \\
\hline Amine, tertiary & {$[\mathrm{C}][\mathrm{NX} 3 ; \mathrm{HO} ; ! \$(\mathrm{NC}=\mathrm{O}) ; ! \$(\mathrm{~N}=\mathrm{O})]([\mathrm{C}])[\mathrm{C}]$} & 20 \\
\hline Amine, aromatic & {$[N ; ! \$(N C=0) ; ! \$(N=0) ; \$(N a)]$} & 21 \\
\hline Amide, primary & {$[\mathrm{CX} 3 ;$ \$ $(\mathrm{C}(=[\mathrm{O}])[\mathrm{NX} 3 ; !$ ! $(\mathrm{N}=0)])](=[0])[\mathrm{N}]([\# 1])[\# 1]$} & 22 \\
\hline Amide, secondary & {$[\mathrm{CX} 3 ; \$(\mathrm{C}(=[0])[\mathrm{NX} 3 ; ! \$(\mathrm{~N}=0)]([\# 6])[\# 1])](=[0])[\mathrm{N}][\# 1]$} & 23 \\
\hline Amide, tertiary & {$[\mathrm{CX} 3 ; \$(\mathrm{C}(=[0])[\mathrm{NX} 3 ; ! \$(\mathrm{~N}=0)]([\# 6])[\# 6])](=[0])[\mathrm{N}]$} & 24 \\
\hline Carbonylperoxynitrate & Table 1 , number 24 & 25 \\
\hline Peroxide & Table 1, number 19 & 26 \\
\hline Hydroperoxide & Table 1 , number 28 & 27 \\
\hline Carbonylperoxyacid & Table 1 , number 25 & 28 \\
\hline Nitrophenol ${ }^{\mathrm{c}}$ & count_nitrophenols (molecule,' $\{$ phenol $\}, '\{$ nitro $\}$ ) & 29 \\
\hline Nitroester $^{\mathrm{a}}$ & $\begin{array}{l}{[\# 6][\mathrm{OX} 2 \mathrm{HO}][\mathrm{CX} 3, \mathrm{CX} 3 \mathrm{H} 1](=\mathrm{O})[\mathrm{C} ; \$(\mathrm{C}[\mathrm{N}](\sim[\mathrm{O}]) \sim[\mathrm{O}]),} \\
\$(\mathrm{CC}[\mathrm{N}](\sim[\mathrm{O}]) \sim[\mathrm{O}]), \$(\mathrm{CCC}[\mathrm{N}](\sim[\mathrm{O}]) \sim[\mathrm{O}]) \\
\$(\mathrm{CCCC}[\mathrm{N}](\sim[\mathrm{O}]) \sim[\mathrm{O}]), \$(\mathrm{CCCCC}[\mathrm{N}](\sim[\mathrm{O}]) \sim[\mathrm{O}])]\end{array}$ & 30 \\
\hline $\begin{array}{l}\text { Carbon number on the } \mathrm{OH} \text { side } \\
\text { of an amide }\end{array}$ & $\begin{array}{l}{[\mathrm{C} ; \$(\mathrm{C}[\mathrm{NX} 3][\mathrm{CH}, \mathrm{CC}](=\mathrm{O})), \$(\mathrm{CC}[\mathrm{NX} 3][\mathrm{CH}, \mathrm{CC}](=\mathrm{O}))} \\
\$(\mathrm{CCC}[\mathrm{NX} 3][\mathrm{CH}, \mathrm{CC}](=\mathrm{O})), \$(\mathrm{CCCC}[\mathrm{NX} 3][\mathrm{CH}, \mathrm{CC}](=\mathrm{O})) \\
\$(\mathrm{CCCCC}[\mathrm{NX} 3[\mathrm{CH}, \mathrm{CC}](=\mathrm{O}))]\end{array}$ & \\
\hline
\end{tabular}

${ }^{a}$ In the case of the calculations of the number of carbons on the acid side of an amide and for nitroester is this table, these patterns provide correct counting for compounds with a maximum of five carbon atoms on the acid side of an amide or in between the ester and the nitro group, respectively. To match cases with higher number of carbon atoms, it is necessary to repeat the specified pattern with an augmented number of carbons specified in the code. ${ }^{b}$ Quantities are calculated from other groups; the code shown is executable string formatting syntax of the Python programming language. Entries in braces \{\} are replaced by the number of matched groups designated by name. ${ }^{\mathrm{c}}$ User-defined functions which access additional molecular structure information for ring structures. molecule is a reserved name indicating an object of the molecule class defined by the Pybel library for our implementation, and entries in quoted braces ' \{\} passed as arguments correspond to the matched substructure prior to enumeration. These functions are provided as part of the companion program (Appendix A). This functional interface abstracts the calculation such that the patterns above can be used with any chemoinformatic software package provided that the implementation of ring enumeration functions is changed accordingly. 
(a)

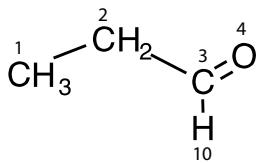

(b)

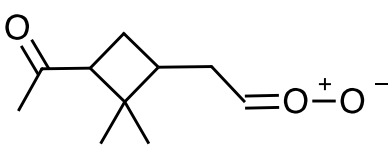

Figure 1. Propionaldehyde (a, SMILES code $\mathrm{CCC}=\mathrm{O}$ ) and compound named APINOOB in MCMv3.2 scheme (b, SMILES code $[\mathrm{O}-][\mathrm{O}+]=\mathrm{CCC} 1 \mathrm{CC}(\mathrm{C}(=\mathrm{O}) \mathrm{C}) \mathrm{C} 1(\mathrm{C}) \mathrm{C})$. The carbon and oxygen atoms are enumerated, together with the hydrogen of the aldehyde group in compound (a).

cific for formic acid has been specified alongside the carboxylic FG.)

In this approach, all atoms in the aldehyde group are matched instead of just the identifying carbon, oxygen, or hydrogen. The advantage of this strict protocol is that we can devise a validation such that each atom in a molecule or chemical system is accounted for by one and only one group - except for polyfunctional carbon - for any proposed set of FGs (Appendix B). Fulfillment of this validation criterion provides a means for interpreting atomic ratios commonly used by the community (e.g., $\mathrm{O}: \mathrm{C}, \mathrm{H}: \mathrm{C}$, and $\mathrm{N}: \mathrm{C}$ ) through contributions of distinctly defined FGs.

Revisiting the aldehyde FG example, an alternative pattern specified only for the purposes of counting FGs for use in SIMPOL. 1 is shown in Table 2. We only describe the bonding environment of the $\mathrm{sp}^{2}$ carbon and count the number of its occurrence, so a single pattern can be used for both formaldehyde and other aldehyde compounds.

A separate set of SMARTS patterns are defined for estimation of $\overline{\mathrm{OS}}_{\mathrm{C}}$. Instead of FGs, these patterns enumerate the type of bond and atom attached to a carbon atom, and its oxidation state is calculated as the sum of the coefficients corresponding to its bonds.

\subsection{Data sets for validation}

The first and the third groups of SMARTS patterns were validated against a set of 99 compounds (Table C1, Appendix C) selected from those used in the development of the SIMPOL.1 method, or occurring in atmospheric aerosol (Sect. 2.3) (Fraser et al., 2003; Grosjean et al., 1996; Fraser et al., 1998), or from the ChemSpider database (Pence and Williams, 2010) (to test for specific functionalities, e.g., secondary amide) or from the MCMv3.2 $\alpha$-pinene oxidation scheme. The patterns corresponding to the first group were further tested against the complete set of compounds present in the $\alpha$-pinene and 1,3,5-trimethylbenzene MCMv3.2 oxidation schemes (408 compounds) in order to achieve a complete counting of all the atoms (carbon, oxygen, nitrogen, and hydrogen atoms) and to avoid attributing heteroatoms to multiple FGs. The second group (Table 1, substructures 33-57) of SMARTS patterns was tested on a set of 26 compounds (Table C2, Appendix C) selected from the ChemSpider database, and the fourth group (Table 3) was

Table 3. List of SMARTS patterns and coefficients associated with each bond type, used to calculate the carbon oxidation state as described in the Sect. 2.

\begin{tabular}{llr}
\hline Bond & SMARTS pattern & Coefficient \\
\hline $\mathrm{C}-\mathrm{H}$ & {$[\# 6][\mathrm{H}]$} & -1 \\
$\mathrm{C}-\mathrm{C}$ & {$[\# 6]-[\# 6]$} & 0 \\
$\mathrm{C}=\mathrm{C}$ & {$[\# 6]=[\# 6]$} & 0 \\
$\mathrm{C} \equiv \mathrm{C}$ & {$[\# 6] \#[\# 6]$} & 0 \\
$\mathrm{C}-\mathrm{O}$ & {$[\# 6]-[\# 8]$} & 1 \\
$\mathrm{C}=\mathrm{O}$ & {$[\# 6]=[\# 8]$} & 2 \\
$\mathrm{C}-\mathrm{N}$ & {$[\# 6]-[\# 7]$} & 1 \\
$\mathrm{C}=\mathrm{N}$ & {$[\# 6]=[\# 7]$} & 2 \\
$\mathrm{C} \equiv \mathrm{N}$ & {$[\# 6] \#[\# 7]$} & 2 \\
$\mathrm{C}-\mathrm{S}$ & {$[\# 6]-[\# 16]$} & 1 \\
$\mathrm{C}=\mathrm{S}$ & {$[\# 6]=[\# 16]$} & 2 \\
$\mathrm{C} \equiv \mathrm{S}$ & {$[\# 6] \#[\# 16]$} & 3 \\
\hline
\end{tabular}

tested on a subset of 3 compounds extracted from the set of compounds used for the validation of the first group.

\subsection{Data sets for example applications: molecules identified by GC-MS measurements and $\alpha$-pinene and 1,3,5-trimethylbenzene photooxidation products specified by the MCMv3.2 mechanism}

A classic data set of organic compounds in primary organic aerosol (OA) from automobile exhaust (Rogge et al., 1993) and wood combustion (Rogge et al., 1998) quantified with GC-MS have been analyzed in order to retrieve the FG abundance of the mixture. Each compound, reported by common name in the literature, was converted to its corresponding SMILES string by querying the ChemSpider database with the Python ChemSpiPy package (Swain, 2015), which wraps the ChemSpider application programming interface. FG composition, $\overline{\mathrm{OS}}_{\mathrm{C}}$, and pure-component vapor pressure for each compound in the different reported mixture types were estimated using the substructure search algorithm described above. The algorithm previously described was applied to calculate the pure-component vapor pressure for each compound $i$ with the SIMPOL.1 model (Pankow and Asher, 2008). The total concentration in both the gas and particle phase of the compounds reported by Rogge et al. (1993), Rogge et al. (1998), and Hildemann et al. (1991) was used to estimate the OA concentration considering a seed concentration $\left(C_{\mathrm{OA}}\right)$ in the predilution channel of $10 \mathrm{mg} \mathrm{m}^{-3}$, assuming fresh cooled emissions (Donahue et al., 2006). After diluting the total OA by a factor of 1000 , the compounds were partitioned between the two phases based on the partitioning coefficient $\xi_{i}$ (xi) calculated from the pure-component saturation concentration $\left(C_{i}^{0}\right)$ as described by Donahue et al. (2006).

FG abundance of the set of compounds incorporated in the MCMv3.2 $\alpha$-pinene and 1,3,5-trimethylbenzene oxidation schemes was analyzed to demonstrate our valida- 
Table 4. Absorption bands in the infrared region of different FGs and the correspondence in Table 1.

\begin{tabular}{|c|c|c|}
\hline No. & $\begin{array}{l}\text { Functional group and } \\
\text { functional groups pattern }\end{array}$ & Wavenumber $\left(\mathrm{cm}^{-1}\right)$ \\
\hline $2,35,36$ & Alkane $\mathrm{C}-\mathrm{H}$ & $\begin{array}{l}2900(\mathrm{C}-\mathrm{H} \text { stretch), } \\
\left.1450 \text { and } 1375 \text { (bend in } \mathrm{CH}_{3}\right) \text {, } \\
1465 \text { (bend in } \mathrm{CH}_{2} \text { ) }\end{array}$ \\
\hline 3 & Alkene $\mathrm{C}-\mathrm{H}$ & $\begin{array}{l}3100(\mathrm{C}-\mathrm{H} \text { stretch}) \\
720 \text { (bend, rocking), } \\
100-650 \text { (out-of-plane bend) }\end{array}$ \\
\hline 37 & Alkyne C-H & 3300 (stretch) \\
\hline 4 & Aromatic $\mathrm{C}-\mathrm{H}$ & $\begin{array}{l}3000 \text { (C-H stretch), } \\
900-690 \text { (out-of-plane bend) }\end{array}$ \\
\hline 38 & Alkyne $\mathrm{C} \equiv \mathrm{C}$ & 2150 (CC stretch) \\
\hline 10,11 & Carboxylic acid $\mathrm{COOH}$ & $\begin{array}{l}3400-2400(\mathrm{O}-\mathrm{H} \text { stretch}), \\
1730-1700(\mathrm{C}=\mathrm{O} \text { stretch}), \\
1320-1210 \text { (stretch) }\end{array}$ \\
\hline $8,9,15,49$ & Aldehyde and ketone & $\begin{array}{l}1740 \text { (aldehyde } \mathrm{C}=\mathrm{O} \text { stretch), } \\
1720-1708 \text { (ketone } \mathrm{C}=\mathrm{O} \text { stretch), } \\
1300-1100 \text { (ketone } \mathrm{C}(\mathrm{C}=\mathrm{O}) \mathrm{C} \text { bend), } \\
2860-2800 \text { and } 2760-1200 \text { (aldehyde } \mathrm{C}-\mathrm{H} \text { stretch) }\end{array}$ \\
\hline $29,30,31$ & Amines & $\begin{array}{l}1640-1560 \text { (N-H bend, in primary amines), } \\
3500-3300 \text { (secondary and primary amines N-H stretch), } \\
1500 \text { (secondary amines N-H bend), } \\
800 \text { (secondary and primary amines N-H out of plane bend), } \\
1350-1000 \text { (C-N stretch) }\end{array}$ \\
\hline 18 (SIMPOL.1 groups) & Amide & $\begin{array}{l}1680-1630(\mathrm{C}=\mathrm{O} \text { stretch}), \\
3350 \text { and } 3180 \text { (primary amide } \mathrm{N}-\mathrm{H} \text { stretch), } \\
3300 \text { (secondary amide } \mathrm{N}-\mathrm{H} \text { stretch), } \\
1640-1550 \text { (primary and secondary amide } \mathrm{N}-\mathrm{H} \text { bend) }\end{array}$ \\
\hline 27 & Organosulfate & $876(\mathrm{C}-\mathrm{O}-\mathrm{S}$ stretch$)$ \\
\hline 23 & Organonitrate & 1280 (symmetric $\mathrm{NO}_{2}$ stretch) \\
\hline 50 & Acid chloride & $\begin{array}{l}1850-1775(\mathrm{C}=\mathrm{O} \text { stretch }) \\
730-550(\mathrm{C}-\mathrm{Cl} \text { stretch })\end{array}$ \\
\hline $22,55,56$ & Nitro & $\begin{array}{l}1600-1640 \text { (aliphatic nitro }-\mathrm{NO}_{2} \text { asymmetric stretch), } \\
1390-1315 \text { (aliphatic nitro }-\mathrm{NO}_{2} \text { symmetric stretch), } \\
1550-1490 \text { (aromatic nitro }-\mathrm{NO}_{2} \text { asymmetric stretch), } \\
1355-1315 \text { (aromatic nitro }-\mathrm{NO}_{2} \text { symmetric stretch) }\end{array}$ \\
\hline
\end{tabular}


Table 4. Continued.

\begin{tabular}{lll}
\hline No. & $\begin{array}{l}\text { Functional group and } \\
\text { functional groups pattern }\end{array}$ & Wavenumber $\left(\mathrm{cm}^{-1}\right)$ \\
\hline 57 & Nitrile & 2250 (stretch, if conjugated $1780-1760)$ \\
\hline 51 & Isocyanate & 2270 (stretch) \\
\hline 52 & Isothiocyanate & 2125 (stretch) \\
\hline 53 & Imine & $1690-1640$ (stretch) \\
\hline 33 & Anhydride & $1830-1800(\mathrm{C}=\mathrm{O}$ stretch), \\
& & $1775-1740(\mathrm{C}-\mathrm{O}$ stretch) \\
\hline $40,41,42$ & Conjugated aldehyde & $1700-1680$ and 1640 (conjugated aldehyde $\mathrm{C}=\mathrm{O}$ with $\mathrm{C}=\mathrm{C}$ in $\alpha$ and $\beta)$, \\
& & $1700-1660$ and $1600-1450($ conjugated aldehyde $\mathrm{C}=\mathrm{O}$ with phenyl), \\
& & $1680($ conjugated aldehyde $\mathrm{C}=\mathrm{O}$ with $\mathrm{C}=\mathrm{C}$ and phenyl), \\
\hline $43,44,45$ & Conjugated ketone & $1700-1675$ and $1644-1617$ (conjugated ketone $\mathrm{C}=\mathrm{O}$ \\
& & and $\alpha, \beta \mathrm{C}=\mathrm{C})$, \\
& & $1700-1680$ and $1600-1450$ (conjugated ketone $\mathrm{C}=\mathrm{O}$ with phenyl), \\
& & $1670-1600$ (conjugated ketone and two phenyl) \\
\hline $46,47,48$ & Conjugated ester & $1740-1715$ and $1640-1625$ (conjugated ester $\mathrm{C}=\mathrm{O}$ and $\alpha, \beta \mathrm{C}=\mathrm{C})$, \\
& & $1740-1715$ and $1600-1450$ (conjugated ester $\mathrm{C}=\mathrm{O}$ and phenyl), \\
& & $1765-1762$ (conjugated ester $\mathrm{C}-\mathrm{O}$ with $\mathrm{C}=\mathrm{C}$ or phenyl)
\end{tabular}

tion scheme. Furthermore, the gas-phase composition generated by $\alpha$-pinene photooxidation in the presence of $\mathrm{NO}_{x}$ $\left(\alpha\right.$-pinene $/ \mathrm{NO}_{x}$ ratio of 1.25 ), with propene as a radical initiator, was simulated using the Kinetic Pre-Processor (KPP; Damian et al., 2002; Sandu and Sander, 2006; Henderson, 2016) incorporating mechanistic information taken from MCMv3.2. Completeness and uniqueness requirements were also tested and matched for the $\alpha$-pinene and propene MCMv3.2 degradation scheme. Initial concentrations of $240 \mathrm{ppb}$ of $\alpha$-pinene and $300 \mathrm{ppb}$ of propene, a relative humidity of $61 \%$, and a continuous irradiation were chosen as simulation conditions.

\section{Results}

\subsection{Validation}

Figure 2 shows that the enumerated FGs used by the SIMPOL.1 method (Table 2) are identical to the values enumerated manually. Matched FTIR FGs in Table 1 (substructures 33-57) are also identical to the true number of FGs in the set of compounds used for evaluation (Table $\mathrm{C} 2$ ), but these are not shown as each group except alkane $\mathrm{CH}$ is matched at most once and a similar plot is uninformative. Figure 3 shows the completeness condition met, and Fig. 4 shows the specificity criterion fulfilled for the first set of chemoinformatic patterns (Table 1, substructures 1-33). The carbon atoms can be accounted by multiple FGs if polyfunctional: methylene and methyl groups are matched two and three times, respec- tively, by alkane $\mathrm{CH}$ group (substructure 1 in Table 1), while the carbon atoms in small molecules included in the test set have only one carbon atom that is matched four times (e.g., methanol, which has three alkane $\mathrm{CH}$ and one alcohol substructures).

\subsection{Example applications}

\subsubsection{Mapping composition in 2-D volatility basis set space}

The algorithm described has been used to project molecular composition of GC-MS and MCM compounds to 2-D VBS space delineated by carbon oxidation and pure-component saturation concentration $\left(C^{0}\right)$ (Fig. 5). The properties of vehicle-related primary $\mathrm{OA}$ and wood combustion compounds measured by GC-MS are generally consistent with those reported for hydrocarbon-like OA and biomass burning $\mathrm{OA}$, respectively, derived from positive matrix factorization (PMF) analysis of AMS spectra (Donahue et al., 2012). The low oxidation state is observed on account of more than $60 \%$ of carbon atoms being associated with methylene groups $\left(-\mathrm{CH}_{2}-\right.$, oxidation state of -2$)$ in long-chain hydrocarbon compounds, and an association to a lesser degree with $\mathrm{CH}$ groups in aromatic rings (oxidation state of -1 ) and methyl groups $\left(-\mathrm{CH}_{3}\right.$, oxidation state of -3$)$.

Most compounds in the MCMv3.2 system correspond to intermediate-volatility organic compounds (IVOCs), with only a small fraction with the semivolatile organic compound (SVOC) regime. When using MCMv3.2 for simulation of 

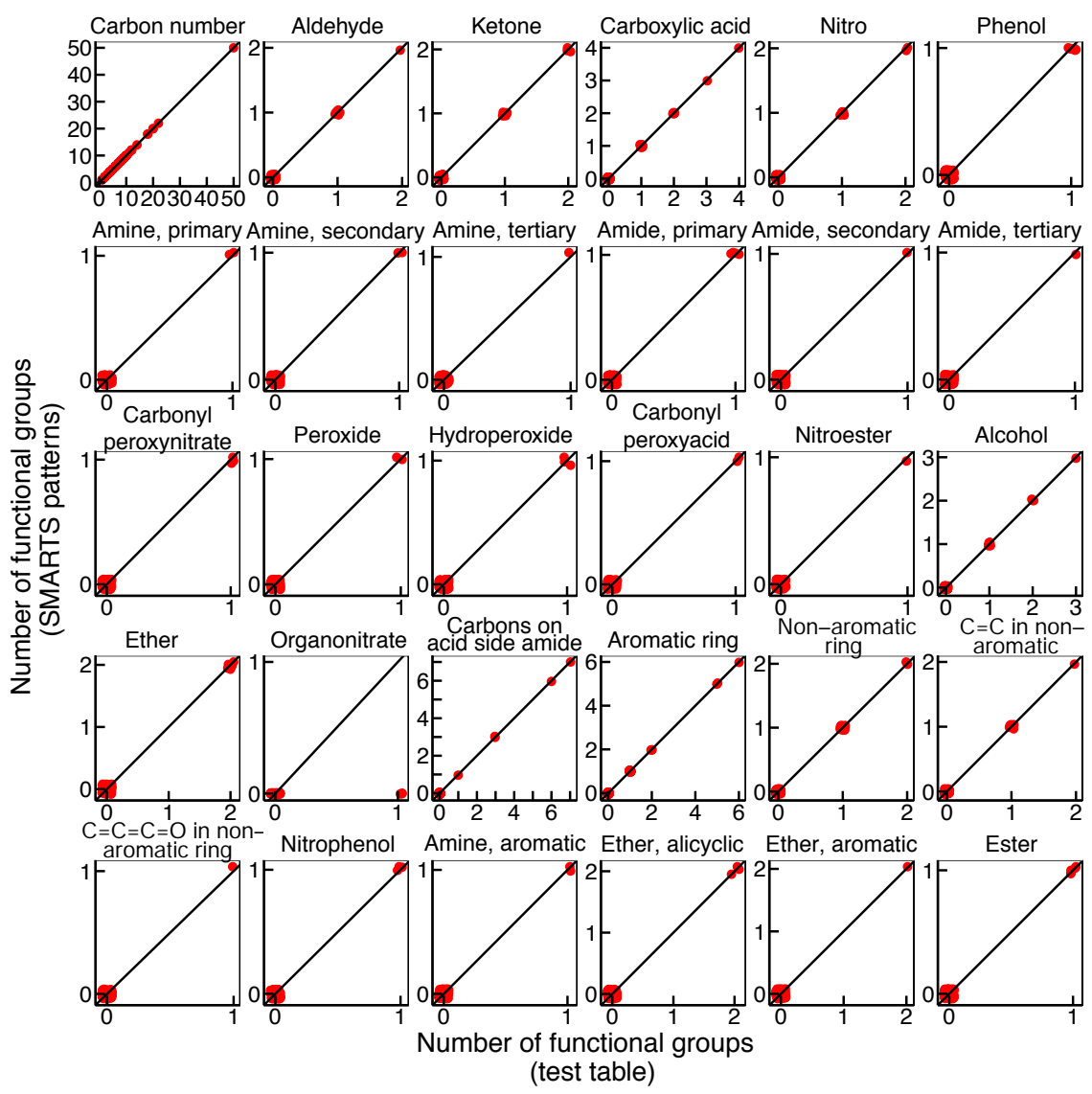

Figure 2. Validation of the developed chemoinformatic patterns for the chemical substructures required in the SIMPOL.1 model (Pankow and Asher, 2008). This validation set includes 99 compounds as described in Sect. 2.

C

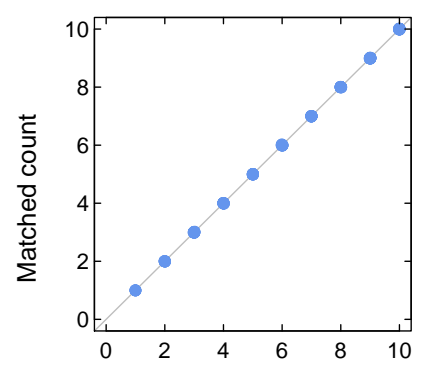

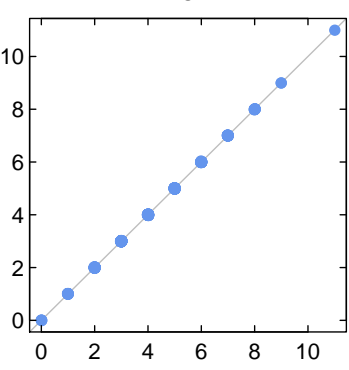

$\mathrm{N}$

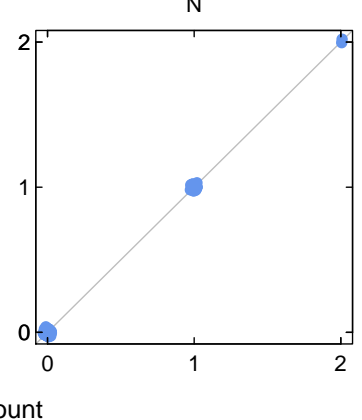

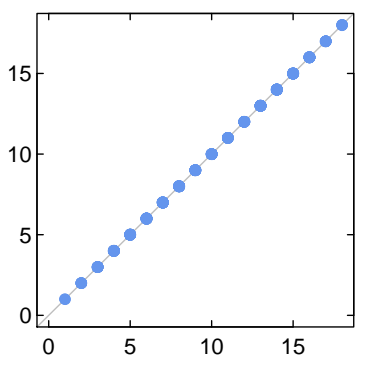

Figure 3. Test of the completeness of matching of all the atoms in the $\alpha$-pinene and 1,3,5-trimethylbenzene degradation scheme in MCMv3.2 by the SMARTS patterns in Table 1, substructures $1-33$.

secondary OA formation, additional mechanisms (e.g., in the condensed phase) are necessary to introduce low-volatility organic compounds (LVOCs) as observed in atmospheric and controlled chamber observations (Ehn et al., 2014; Shiraiwa et al., 2014). Higher oxidation states than for compounds in the GC-MS set are observed on account of the larger number of functional groups containing electronegative atoms (oxygen and nitrogen) bonded to carbon.

\subsubsection{Source apportionment}

In Fig. 6, the FG distributions of aerosol collected during wood-burning and vehicle emission studies (Rogge et al., 1993, 1998) have been compared to estimates from FTIR measurements of ambient samples separated by factor analytic decomposition (PMF; Paatero and Tapper, 1994) during September 2008 in California (Hawkins and Russell, 2010). The studies by Rogge et al. $(1993,1998)$ have been chosen 


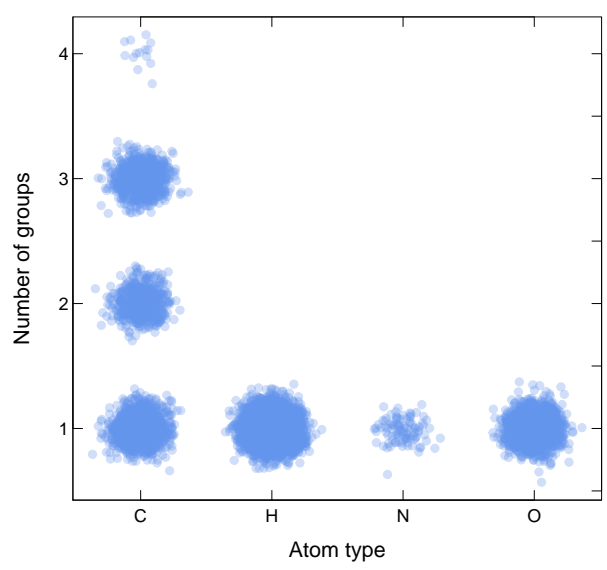

Figure 4. Test for the uniqueness of matching for each atom. Number of times a specific atom has been matched in the $\alpha$-pinene and 1,3,5-trimethylbenzene degradation scheme in MCMv3.2 by the SMARTS patterns in Table 1, substructures 1-33. Oxygen, nitrogen, and hydrogen atoms are matched only once. The carbon atoms are matched multiple times when multifunctional.

as they have been used as a reference in the study of composition of organic aerosol from combustion sources (Heringa et al., 2012). The FTIR factor components from this study are consistent with similarly labeled factors from other field campaigns (Russell et al., 2011). The GC-MS reports approximately $20 \%$ of the OA mass (Fine et al., 2002), while the FTIR quantifies around $90 \%$ (Maria et al., 2003); these fractions form the bases for comparisons. For the study using FTIR, the biomass burning fraction was approximately $50 \%$ of the total OA during intensive fire periods, and the fossil fuel combustion comprised $95 \%$ of the overall OA during the campaign (Hawkins and Russell, 2010).

From this comparison, we find that the oxidized fraction is much higher in the biomass burning aerosol composition estimated by FTIR. The high abundance of alkane $\mathrm{CH}$ bonds in the compounds reported by GC-MS can be explained by the preference of this analytical method to characterize the least oxidized fraction of the collected aerosol. While high abundances of carbonyl groups are reported in FTIR measurements of biomass burning aerosol (Liu et al., 2009; Russell et al., 2009; Hawkins and Russell, 2010), more recent methods including advanced derivatization (Dron et al., 2010) are necessary for quantification of carbonyl-containing compounds by GC-MS. In addition, neither amine compounds nor levoglucosan were reported in this GC-MS study. Levoglucosan is a polysaccharide compound often used as a tracer for burning and decomposition of cellulose reported in modern GC-MS measurements (Simoneit, 1999). However, FTIR does not report a high fraction of alcohol $\mathrm{COH}$ as levoglucosan near particular fuel sources may be found mostly in supermicron-diameter particles (Radzi bin Abas et al., 2004) (submicron OA was analyzed by Hawkins and Russell, 2010), its degradation in the atmosphere is rapid

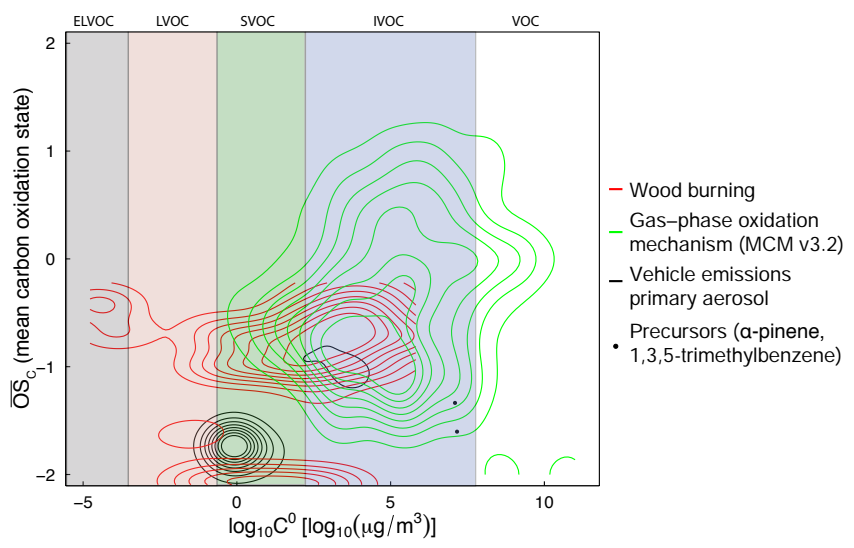

Figure 5. Logarithm of the pure-component saturation concentration $\left(\log _{10} C^{0}\right)$ and mean carbon oxidation state of each compound $\left(\overline{\mathrm{OS}}_{\mathrm{C}}\right)$ measured by Rogge et al. (1993) and Rogge et al. (1998) for biomass burning and vehicle emissions sources (green and blue lines), as well as of each molecule constituting the MCMv3.2 gas-phase oxidation mechanism of $\alpha$-pinene and 1,3,5-trimethylbenzene. The lines in the plot denote isolines $(0,0.1, \ldots, 0.9)$ of the maximum density estimate for the different compound sets. The black dots indicate the position of $\alpha$-pinene and 1,3,5-trimethylbenzene. The area of the plot is divided into volatility regions according to the classification of Donahue et al. (2012).

(Hennigan et al., 2010; Cubison et al., 2011; Lai et al., 2014), and the overall mass contribution to biomass burning OA is small (less than $2 \%$ by mass; Leithead et al., 2006).

Both estimation methods agree that more than $90 \%$ of OM mass is composed of alkane $\mathrm{CH}$ for vehicle sources. The fractions characterized by GC-MS and FTIR with PMF have associated uncertainties from derivatization and thermal separation in the chromatography column or in statistical separation, respectively, and lead to different fractions of mass reported. However, the approximate consistency in FG abundances estimated by the two methods suggests that the fraction not analyzed by the GC-MS may not vary significantly from the measured fraction by FTIR in these aerosol types.

\subsubsection{Oxygenated FG contribution to $\mathrm{O}: \mathrm{C}$ ratio}

Using the first set of SMARTS patterns we are able to match all the oxygen atoms, attributing them to specific FGs, in the $\alpha$-pinene and 1,3,5-trimethylbenzene MCMv3.2 oxidation mechanisms. We can therefore calculate the contribution of each FG to the total $\mathrm{O}: \mathrm{C}$ ratio of the gas-phase mixture. In Fig. 7, contributions of $\mathrm{FGs}$ to the $\mathrm{O}: \mathrm{C}$ ratio of the gasphase mixture generated by $\alpha$-pinene photooxidation in low$\mathrm{NO}_{x}$ conditions (Sect. 2.3) is reported as a function of irradiation time. A singular peroxyacyl nitrate compound (peroxyacetyl nitrate) accounts for $26 \%$ of the total gas-phase mass. The peroxyacyl nitrate functional group furthermore accounts for the greatest fraction of the total $\mathrm{O}: \mathrm{C}$ ratio after $20 \mathrm{~h}$ of simulation ( $53 \%$ of the total $\mathrm{O}: \mathrm{C}$ ), as it contains five 
GC-MS

(a) Wood burning

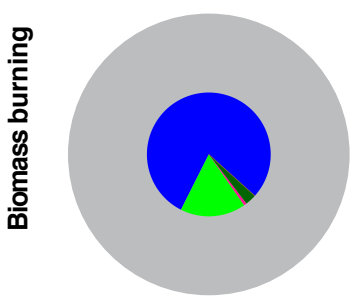

(b)
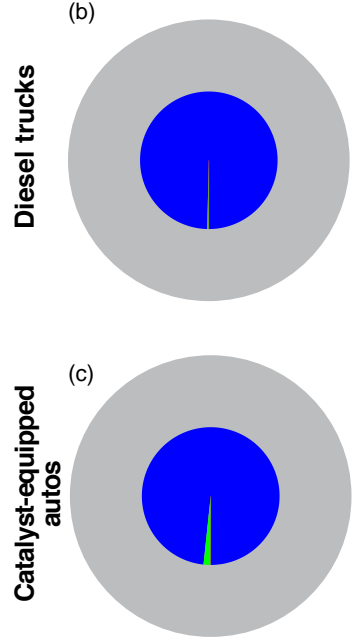

FTIR-PMF

(d) Wood + biomass burning

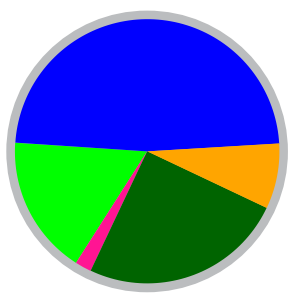

(e)

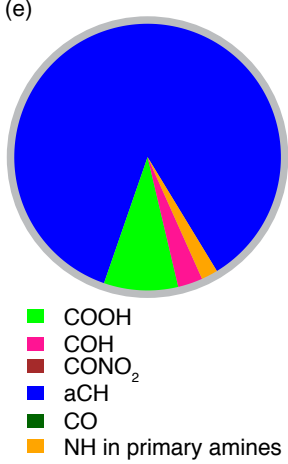

Figure 6. Comparison of the FG distribution of the quantified fraction measured by GC-MS (a, b, c; Rogge et al., 1998; Rogge et al., 1993) and FTIR-PMF (d and e; Hawkins and Russell, 2010) in aerosol emitted by biomass burning (a, d) and vehicle emission (b, c, e) sources. The gray area is the OA fraction unresolved by the two different analytical techniques used (around $80 \%$ for GC-MS and around $10 \%$ for FTIR). The type of biomass burning is specified in the pie charts (a, d).

oxygen atoms per FG. A full analysis on oxidation products with gas-particle partitioning is discussed by Ruggeri et al. (2016). This type of analysis can provide intermediate information that is useful to suggest constraints on the form of oxygenation (and resulting change in organic mixture vapor pressure) assumed by simplified models such as the Statistical Oxidation Model (Cappa and Wilson, 2012).

\section{Conclusions}

We introduced the application of chemoinformatic tools that allow us to perform substructure matching in molecules to enumerate FGs present in compounds relevant for organic aerosol chemistry. We developed $50+$ substructure patterns

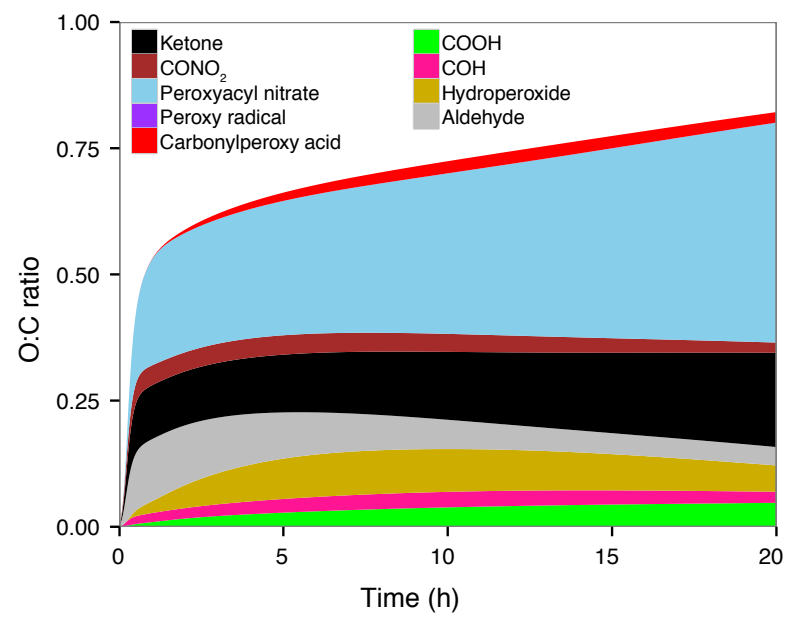

Figure 7. Time series of FG contributions to the total $\mathrm{O}: \mathrm{C}$ of the gas phase generated by photooxidation of $\alpha$-pinene in low- $\mathrm{NO}_{x}$ regime, simulated using the MCMv3.2 degradation scheme.

and validated them over a list of 125 compounds that were selected in order to account for all the functional groups (FGs) represented. We demonstrate how these tools can facilitate intercomparisons between GC-MS and FTIR measurements as well as mapping of compounds onto the 2-D VBS space described by pure-component vapor pressure and oxidation state.

We further introduce a novel approach for defining a set of patterns which accounts for each atom in a chemical system once and only once (except for polyfunctional carbon atoms associated with multiple FGs). This condition is confirmed by an atomic-level validation scheme applied to chemically explicit $\alpha$-pinene and 1,3,5-trimethylbenzene degradation mechanisms. This validation scheme provides an intermediate resolution between molecular speciation and atomic composition, and permits apportionment of conventionally aggregated quantities such as $\mathrm{O}: \mathrm{C}, \mathrm{H}: \mathrm{C}$, and $\mathrm{N}: \mathrm{C}$ to contributions from individual FGs. We illustrate its application to the photochemical degradation of $\alpha$-pinene from speciated simulations using MCMv3.2.

These applications can be further adapted for other methods developed to match substructures for other measurements or to enumerate groups used in group contribution methods for estimation of vapor pressures, activity coefficients, and Henry's law constants (Raventos-Duran et al., 2010; Compernolle et al., 2011; Zuend et al., 2011). The proposed validation approach can also be followed to define FG patterns containing sulfur and halide bonds that absorb in the infrared region presently not included in this work. 


\section{Appendix A: Software program}

ASCII tables of the SMARTS patterns and the Python program assembled for this work are released as a Python program, APRL-SSP (APRL Substructure Search Program; Takahama, 2015), licensed under the GNU Public License version 3.0. In this program, series of scripts allow users to access the functionality of Pybel and ChemSpiPy through input and output files defined as CSV-formatted tables.

\section{Appendix B: Group validation}

Let us consider a set of atoms $A$ in molecule $k$ and a set of FGs $G$. $\left\{a: \in A_{k}, a \in g\right\}$ denotes the set of atoms in molecule $k$ which also is a member of group $g$, where $g \in G$. Completeness of $G$ is defined by the condition that the combination of atoms matched by all groups in $G$ comprises the full set of atoms $A_{k}$ for every molecule:

$\bigcup_{g \in G}\left\{a: a \in A_{k}, a \in g\right\}=A_{k} \quad \forall k$.

Specificity or minimal redundancy in $G$ is defined by the condition that the intersection of atoms from all groups, excluding the set of polyfunctional carbon atoms $C_{k}^{\mathrm{p}} \subset A_{k}$, comprises the empty set:

$\bigcap_{g \in G}\left\{a: a \in A_{k}, a \in g\right\} \backslash C_{k}^{\mathrm{p}}=\varnothing \quad \forall k$. 
Appendix C: Compounds used for testing the chemoinformatic patterns

Table C1. List of the compounds used to test the chemoinformatic patterns used in the SIMPOL.1 (Pankow and Asher, 2008) group contribution method to calculate pure-component vapor pressure (Table 2).

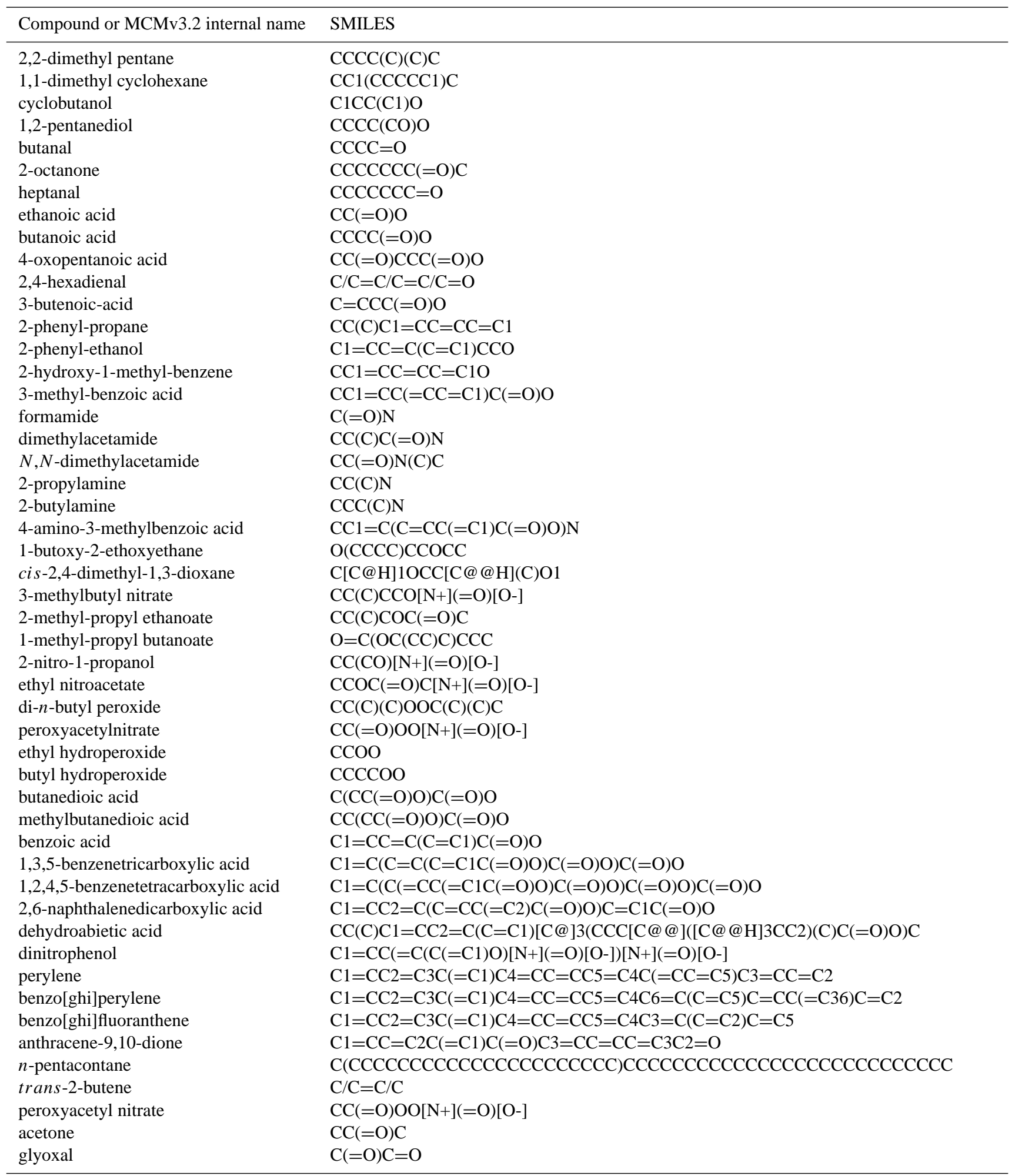


Table C1. Continued.

\begin{tabular}{|c|c|}
\hline Compound or MCMv3.2 internal name & SMILES \\
\hline crotonaldehyde & $\mathrm{C} / \mathrm{C}=\mathrm{C} / \mathrm{C}=\mathrm{O}$ \\
\hline cyclohexanone & $\mathrm{C} 1 \mathrm{CCC}(=\mathrm{O}) \mathrm{CC} 1$ \\
\hline cyclohex-2-eneone & $\mathrm{C} 1 \mathrm{CC}=\mathrm{CC}(=\mathrm{O}) \mathrm{C} 1$ \\
\hline 1-(4-methyl-phenyl)-ethanone & $\mathrm{Cc} 1 \operatorname{ccc}(\operatorname{cc} 1) \mathrm{C}(=\mathrm{O}) \mathrm{C}$ \\
\hline 1-phenyl-1-butanone & $\operatorname{CCCC}(=\mathrm{O}) \operatorname{cocccc} 1$ \\
\hline 2,4-dimethyl-benzaldehyde & $\mathrm{CC} 1=\mathrm{CC}(=\mathrm{C}(\mathrm{C}=\mathrm{C} 1) \mathrm{C}=\mathrm{O}) \mathrm{C}$ \\
\hline cyclohexane & $\mathrm{C} 1 \mathrm{CCCCC} 1$ \\
\hline 1,1-dimethyl cyclopentane & $\mathrm{CC} 1(\mathrm{CCCC} 1) \mathrm{C}$ \\
\hline 3-ethyl-phenol & $\mathrm{CCc} 1 \operatorname{ccc}(\mathrm{c} 1) \mathrm{O}$ \\
\hline$p$-hydroxybiphenyl & $\mathrm{C} 1=\mathrm{CC}=\mathrm{C}(\mathrm{C}=\mathrm{C} 1) \mathrm{C} 2=\mathrm{CC}=\mathrm{C}(\mathrm{C}=\mathrm{C} 2) \mathrm{O}$ \\
\hline cis-2-butene-1,4-diol & $\mathrm{C}(/ \mathrm{C}=\mathrm{C} / \mathrm{CO}) \mathrm{O}$ \\
\hline oct-2-en-4-ol & $\mathrm{OC}(/ \mathrm{C}=\mathrm{C} / \mathrm{C}) \mathrm{CCCC}$ \\
\hline 1,7-heptanediol & $\mathrm{C}(\mathrm{CCCO}) \mathrm{CCCO}$ \\
\hline pinic acid & $\mathrm{CC} 1(\mathrm{C}(\mathrm{CC} 1 \mathrm{C}(=\mathrm{O}) \mathrm{O}) \mathrm{CC}(=\mathrm{O}) \mathrm{O}) \mathrm{C}$ \\
\hline norpinic acid & $\mathrm{CC} 1(\mathrm{C}(\mathrm{CC} 1 \mathrm{C}(=\mathrm{O}) \mathrm{O}) \mathrm{C}(=\mathrm{O}) \mathrm{O}) \mathrm{C}$ \\
\hline octadeca-9-enoic acid & $\mathrm{CCCCCCCC} / \mathrm{C}=\mathrm{C} / \mathrm{CCCCCCCC}(=\mathrm{O}) \mathrm{O}$ \\
\hline pentamethyl benzoic acid & $\mathrm{Cc} 1 \mathrm{c}(\mathrm{c}(\mathrm{c}(\mathrm{c}(\mathrm{c} 1 \mathrm{C}) \mathrm{C}) \mathrm{C}(=\mathrm{O}) \mathrm{O}) \mathrm{C}) \mathrm{C}$ \\
\hline heptanamide & $\operatorname{CCCCCCC}(=\mathrm{O}) \mathrm{N}$ \\
\hline diethylbutanamide & $\mathrm{CCC}(\mathrm{CC})(\mathrm{CC}) \mathrm{C}(=\mathrm{O}) \mathrm{N}$ \\
\hline$n$-ethyl- $n$-phenylamine & $\mathrm{CCNc} 1 \mathrm{cccc} 1$ \\
\hline triethanolamine & $\mathrm{C}(\mathrm{CO}) \mathrm{N}(\mathrm{CCO}) \mathrm{CCO}$ \\
\hline methyl dimethoxyethanoate & $\mathrm{COC}(\mathrm{C}(=\mathrm{O}) \mathrm{OC}) \mathrm{OC}$ \\
\hline methyl benzoate & $\operatorname{COC}(=0) \operatorname{c} 1 \operatorname{ccccc} 1$ \\
\hline 2-methyl-propyl benzoate & $\mathrm{CC}(\mathrm{C}) \mathrm{COC}(=\mathrm{O}) \mathrm{c} 1 \mathrm{ccccc} 1$ \\
\hline 1,3-dioxolan & $\mathrm{C} 1 \mathrm{COCO} 1$ \\
\hline 2-phenyl-1,3-dioxolane & $\mathrm{c} 1 \mathrm{ccc}(\mathrm{cc} 1) \mathrm{C} 2 \mathrm{OCCO} 2$ \\
\hline 2,4-dimethoxybenzoic acid & $\mathrm{COc} 1 \mathrm{ccc}(\mathrm{c}(\mathrm{c} 1) \mathrm{OC}) \mathrm{C}(=\mathrm{O}) \mathrm{O}$ \\
\hline phenylmethyl nitrate & $\mathrm{C} 1=\mathrm{CC}=\mathrm{C}(\mathrm{C}=\mathrm{C} 1) \mathrm{CO}[\mathrm{N}+](=\mathrm{O})[\mathrm{O}-]$ \\
\hline 2,4-dinitrophenol & $\operatorname{clcc}(\operatorname{cc}(\operatorname{cc} 1[\mathrm{~N}+](=\mathrm{O})[\mathrm{O}-])[\mathrm{N}+](=\mathrm{O})[\mathrm{O}-]) \mathrm{O}$ \\
\hline 4-nitrophenol & $\operatorname{clcc}(\operatorname{ccc} 1[\mathrm{~N}+](=\mathrm{O})[\mathrm{O}-]) \mathrm{O}$ \\
\hline 2-methyl-6-nitrobenzoic acid & $\mathrm{Cc} 1 \operatorname{cccc}(\mathrm{c} 1 \mathrm{C}(=\mathrm{O}) \mathrm{O})[\mathrm{N}+](=\mathrm{O})[\mathrm{O}-]$ \\
\hline di-(1-methyl-propyl) peroxide & $\mathrm{CCC}(\mathrm{C}) \mathrm{OOC}(\mathrm{C}) \mathrm{CC}$ \\
\hline ethylbutanamide & $\mathrm{CCCC}(=\mathrm{O}) \mathrm{NCC}$ \\
\hline $\mathrm{C} 811 \mathrm{CO} 3$ & {$[\mathrm{O}] \mathrm{OC}(=\mathrm{O}) \mathrm{CC} 1 \mathrm{CC}(\mathrm{C}(=\mathrm{O}) \mathrm{O}) \mathrm{C} 1(\mathrm{C}) \mathrm{C}$} \\
\hline APINBOO & {$[\mathrm{O}-][\mathrm{O}+]=\mathrm{CCC} 1 \mathrm{CC}(\mathrm{C}(=\mathrm{O}) \mathrm{C}) \mathrm{C} 1(\mathrm{C}) \mathrm{C}$} \\
\hline $\mathrm{C} 106 \mathrm{O} 2$ & $\mathrm{O}=\mathrm{CCC}(=\mathrm{O}) \mathrm{CC}(\mathrm{C}(=\mathrm{O}) \mathrm{C}) \mathrm{C}(\mathrm{C})(\mathrm{C}) \mathrm{O}[\mathrm{O}]$ \\
\hline $\mathrm{C} 721 \mathrm{O}$ & $\mathrm{OC}(=\mathrm{O}) \mathrm{C} 1 \mathrm{CC}([\mathrm{O}]) \mathrm{C} 1(\mathrm{C}) \mathrm{C}$ \\
\hline 2,2-dimethylpropaneperoxoic acid & $\mathrm{OOC}(=\mathrm{O}) \mathrm{C}(\mathrm{C})(\mathrm{C}) \mathrm{C}$ \\
\hline APINCO & $\mathrm{CC} 1=\mathrm{CCC}(\mathrm{CC} 1 \mathrm{O}) \mathrm{C}(\mathrm{C})(\mathrm{C})[\mathrm{O}]$ \\
\hline $\mathrm{C} 89 \mathrm{CO} 2$ & $\mathrm{O}=\mathrm{CCC} 1 \mathrm{CC}(\mathrm{C}(=\mathrm{O})[\mathrm{O}]) \mathrm{C} 1(\mathrm{C}) \mathrm{C}$ \\
\hline C10PAN2 & $\mathrm{O}=\mathrm{N}(=\mathrm{O}) \mathrm{OOC}(=\mathrm{O}) \mathrm{CC} 1 \mathrm{CC}(\mathrm{C}(=\mathrm{O}) \mathrm{C}) \mathrm{C} 1(\mathrm{C}) \mathrm{C}$ \\
\hline pinanol & $\mathrm{O}=\mathrm{N}(=\mathrm{O}) \mathrm{OC} 1(\mathrm{C}) \mathrm{C}(\mathrm{O}) \mathrm{CC} 2 \mathrm{CC} 1 \mathrm{C} 2(\mathrm{C}) \mathrm{C}$ \\
\hline $\mathrm{C} 811 \mathrm{CO} 3 \mathrm{H}$ & $\mathrm{OOC}(=\mathrm{O}) \mathrm{CC} 1 \mathrm{CC}(\mathrm{C}(=\mathrm{O}) \mathrm{O}) \mathrm{C} 1(\mathrm{C}) \mathrm{C}$ \\
\hline $\mathrm{C} 106 \mathrm{OOH}$ & $\mathrm{O}=\mathrm{CCC}(=\mathrm{O}) \mathrm{CC}(\mathrm{C}(=\mathrm{O}) \mathrm{C}) \mathrm{C}(\mathrm{C})(\mathrm{C}) \mathrm{OO}$ \\
\hline ethyl sulfate & $\operatorname{ccOS}(=\mathrm{O})(=\mathrm{O}) \mathrm{O}$ \\
\hline toluene & Cc1ccect 1 \\
\hline nitroperoxymethane & $\operatorname{COON}(=\mathrm{O})=\mathrm{O}$ \\
\hline diethylamine & $\mathrm{CCNCC}$ \\
\hline dimethylamine & $\mathrm{CNC}$ \\
\hline
\end{tabular}


Table C2. List of compounds used to test the substructures 33-57 in Table 1.

\begin{tabular}{|c|c|}
\hline Compound name & SMILES \\
\hline propane & $\mathrm{CCC}$ \\
\hline pentyne & $\mathrm{CCCC \# C}$ \\
\hline benzene & $\mathrm{c} 1 \mathrm{ccccc} 1$ \\
\hline pentenal & $\mathrm{CC} / \mathrm{C}=\mathrm{C} / \mathrm{C}=\mathrm{O}$ \\
\hline benzaldehyde & $\operatorname{c} 1 \operatorname{ccc}(\operatorname{cc} 1) \mathrm{C}=\mathrm{O}$ \\
\hline cinnamaldehyde & $\mathrm{c} 1 \mathrm{ccc}(\mathrm{cc} 1) \mathrm{C}=\mathrm{CC}=\mathrm{O}$ \\
\hline mesityloxide & $\mathrm{CC}(=\mathrm{CC}(=\mathrm{O}) \mathrm{C}) \mathrm{C}$ \\
\hline acetophenone & $\mathrm{CC}(=\mathrm{O}) \mathrm{c} 1 \operatorname{ccccc} 1$ \\
\hline benzophenone & $\operatorname{c} 1 \operatorname{ccc}(\operatorname{cc} 1) \mathrm{C}(=\mathrm{O}) \mathrm{c} 2 \operatorname{cccc} 2$ \\
\hline cyclopentanone & $\mathrm{C} 1 \mathrm{CCC}(=\mathrm{O}) \mathrm{C} 1$ \\
\hline biacetyl & $\mathrm{CC}(=\mathrm{O}) \mathrm{C}(=\mathrm{O}) \mathrm{C}$ \\
\hline pentadione & $\mathrm{CC}(=\mathrm{O}) \mathrm{CC}(=\mathrm{O}) \mathrm{C}$ \\
\hline methylmethacrylate & $\mathrm{CC}(=\mathrm{C}) \mathrm{C}(=\mathrm{O}) \mathrm{OC}$ \\
\hline methylbenzoate & $\mathrm{COC}(=\mathrm{O}) \mathrm{c} 1 \mathrm{cccc} 1$ \\
\hline vinylacetate & $\mathrm{CC}(=\mathrm{O}) \mathrm{OC}=\mathrm{C}$ \\
\hline butyrolactone & $\mathrm{C} 1 \mathrm{CC}(=\mathrm{O}) \mathrm{OC} 1$ \\
\hline ethanoic anhydride & $\mathrm{CC}(=\mathrm{O}) \mathrm{OC}(=\mathrm{O}) \mathrm{C}$ \\
\hline acetyl chloride & $\mathrm{CC}(=\mathrm{O}) \mathrm{Cl}$ \\
\hline propionitrile & $\mathrm{CCC \# N}$ \\
\hline methyl isocyanate & $\mathrm{CN}=\mathrm{C}=\mathrm{O}$ \\
\hline methyl isothiocyanate & $\mathrm{CN}=\mathrm{C}=\mathrm{S}$ \\
\hline ethanimine & $\mathrm{CC}=\mathrm{N}$ \\
\hline acetone oxime & $\mathrm{CC}(=\mathrm{NO}) \mathrm{C}$ \\
\hline nitrobenzene & $\operatorname{clccc}(\operatorname{cc} 1)[\mathrm{N}+](=\mathrm{O})[\mathrm{O}-]$ \\
\hline nitropropane & $\mathrm{CCC}[\mathrm{N}+](=\mathrm{O})[\mathrm{O}-]$ \\
\hline
\end{tabular}


Acknowledgements. The authors acknowledge funding from the Swiss National Science Foundation (200021_143298). The authors would like to thank S. Shipley for her initial contributions to the SMARTS pattern definitions, and to B. Henderson for his KPP code repository and initial guidance.

Edited by: B. Ervens

\section{References}

Aimanant, S. and Ziemann, P. J.: Development of Spectrophotometric Methods for the Analysis of Functional Groups in Oxidized Organic Aerosol, Aerosol Sci. Tech., 47, 581-591, doi:10.1080/02786826.2013.773579, 2013.

Aumont, B., Szopa, S., and Madronich, S.: Modelling the evolution of organic carbon during its gas-phase tropospheric oxidation: development of an explicit model based on a self generating approach, Atmos. Chem. Phys., 5, 2497-2517, doi:10.5194/acp-52497-2005, 2005.

Balaban, A. T.: Applications of graph theory in chemistry, J. Chem. Inf. Comp. Sci., 25, 334-343, doi:10.1021/ci00047a033, 1985.

Barley, M. H., Topping, D., Lowe, D., Utembe, S., and McFiggans, G.: The sensitivity of secondary organic aerosol (SOA) component partitioning to the predictions of component properties Part 3: Investigation of condensed compounds generated by a near-explicit model of VOC oxidation, Atmos. Chem. Phys., 11, 13145-13159, doi:10.5194/acp-11-13145-2011, 2011.

Barnard, J. M.: Substructure searching methods: Old and new, J. Chem. Inf. Comp. Sci., 33, 532-538, doi:10.1021/ci00014a001, 1993.

Berger, F., Flamm, C., Gleiss, P. M., Leydold, J., and Stadler, P. F.: Counterexamples in Chemical Ring Perception, J. Chem. Inf. Comp. Sci., 44, 323-331, doi:10.1021/ci030405d, 2004.

Bloss, C., Wagner, V., Jenkin, M. E., Volkamer, R., Bloss, W. J., Lee, J. D., Heard, D. E., Wirtz, K., Martin-Reviejo, M., Rea, G., Wenger, J. C., and Pilling, M. J.: Development of a detailed chemical mechanism (MCMv3.1) for the atmospheric oxidation of aromatic hydrocarbons, Atmos. Chem. Phys., 5, 641-664, doi:10.5194/acp-5-641-2005, 2005.

Brown, W. H., Foote, C. S., Iverson, B. L., and Anslyn, E. V.: Organic Chemistry, Books/Cole, Cengage learning, 20 Davis Drive, Belmont, CA 94002-3098, USA, 2012.

Cappa, C. D. and Wilson, K. R.: Multi-generation gas-phase oxidation, equilibrium partitioning, and the formation and evolution of secondary organic aerosol, Atmos. Chem. Phys., 12, 9505-9528, doi:10.5194/acp-12-9505-2012, 2012.

Chan, M. N., Nah, T., and Wilson, K. R.: Real time in situ chemical characterization of sub-micron organic aerosols using Direct Analysis in Real Time mass spectrometry (DART-MS): the effect of aerosol size and volatility, Analyst, 138, 3749-3757, doi:10.1039/C3AN00168G, 2013.

Chhabra, P. S., Lambe, A. T., Canagaratna, M. R., Stark, H., Jayne, J. T., Onasch, T. B., Davidovits, P., Kimmel, J. R., and Worsnop, D. R.: Application of high-resolution time-of-flight chemical ionization mass spectrometry measurements to estimate volatility distributions of a-pinene and naphthalene oxidation products, Atmos. Meas. Tech., 8, 1-18, doi:10.5194/amt-8-1-2015, 2015.
Cleveland, M. J., Ziemba, L. D., Griffin, R. J., Dibb, J. E., Anderson, C. H., Lefer, B., and Rappengluck, B.: Characterization of urban aerosol using aerosol mass spectrometry and proton nuclear magnetic resonance spectroscopy, Atmos. Environ., 54, 511-518, doi:10.1016/j.atmosenv.2012.02.074, 2012.

Compernolle, S., Ceulemans, K., and Müller, J.-F.: EVAPORATION: a new vapour pressure estimation methodfor organic molecules including non-additivity and intramolecular interactions, Atmos. Chem. Phys., 11, 9431-9450, doi:10.5194/acp-119431-2011, 2011.

Craig, R. L., Bondy, A. L., and Ault, A. P.: Surface Enhanced Raman Spectroscopy Enables Observations of Previously Undetectable Secondary Organic Aerosol Components at the Individual Particle Level, Anal. Chem., 87, 7510-7514, doi:10.1021/acs.analchem.5b01507, 2015.

Cubison, M. J., Ortega, A. M., Hayes, P. L., Farmer, D. K., Day, D., Lechner, M. J., Brune, W. H., Apel, E., Diskin, G. S., Fisher, J. A., Fuelberg, H. E., Hecobian, A., Knapp, D. J., Mikoviny, T., Riemer, D., Sachse, G. W., Sessions, W., Weber, R. J., Weinheimer, A. J., Wisthaler, A., and Jimenez, J. L.: Effects of aging on organic aerosol from open biomass burning smoke in aircraft and laboratory studies, Atmos. Chem. Phys., 11, 12049-12064, doi:10.5194/acp-11-12049-2011, 2011.

Damian, V., Sandu, A., Damian, M., Potra, F., and Carmichael, G. R.: The kinetic preprocessor KPP-a software environment for solving chemical kinetics, Comput. Chem. Eng., 26, 1567-1579, doi:10.1016/S0098-1354(02)00128-X, 2002.

Daumit, K. E., Kessler, S. H., and Kroll, J. H.: Average chemical properties and potential formation pathways of highly oxidized organic aerosol, Faraday Discuss., 165, 181-202, doi:10.1039/C3FD00045A, 2013.

DAYLIGHT Chemical Information Systems, Inc.: available at: http://www.daylight.com/dayhtml/doc/theory/theory.smarts. html, last access: 30 September 2015.

Decesari, S., Facchini, M. C., Fuzzi, S., and Tagliavini, E.: Characterization of water-soluble organic compounds in atmospheric aerosol: A new approach, J. Geophys. Res.-Atmos., 105, 14811489, doi:10.1029/1999JD900950, 2000.

Donahue, N. M.: Atmospheric chemistry: The reaction that wouldn't quit, Nature Chemistry, 3, 98-99, doi:10.1038/nchem.941, 2011.

Donahue, N. M., Robinson, A. L., Stanier, C. O., and Pandis, S. N.: Coupled partitioning, dilution, and chemical aging of semivolatile organics, Environ. Sci. Technol., 40, 2635-2643, doi:10.1021/es052297c, 2006.

Donahue, N. M., Henry, K. M., Mentel, T. F., Kiendler-Scharr, A., Spindler, C., Bohn, B., Brauers, T., Dorn, H. P., Fuchs, H., Tillmann, R., Wahner, A., Saathoff, H., Naumann, K.-H., Moehler, O., Leisner, T., Mueller, L., Reinnig, M.-C., Hoffmann, T., Salo, K., Hallquist, M., Frosch, M., Bilde, M., Tritscher, T., Barmet, P., Praplan, A. P., DeCarlo, P. F., Dommen, J., Prevot, A. S. H., and Baltensperger, U.: Aging of biogenic secondary organic aerosol via gas-phase $\mathrm{OH}$ radical reactions, P. Natl. Acad. Sci. USA, 109, 13503-13508, doi:10.1073/pnas.1115186109, 2012.

Downs, G. M., Gillet, V. J., Holliday, J. D., and Lynch, M. F.: Review of ring perception algorithms for chemical graphs, J. Chem. Inf. Comp. Sci., 29, 172-187, doi:10.1021/ci00063a007, 1989.

Dron, J., El Haddad, I., Temime-Roussel, B., Jaffrezo, J.-L., Wortham, H., and Marchand, N.: Functional group composi- 
tion of ambient and source organic aerosols determined by tandem mass spectrometry, Atmos. Chem. Phys., 10, 7041-7055, doi:10.5194/acp-10-7041-2010, 2010.

Ehn, M., Thornton, J. A., Kleist, E., Sipilä, M., Junninen, H., Pullinen, I., Springer, M., Rubach, F., Tillmann, R., Lee, B., LopezHilfiker, F., Andres, S., Acir, I.-H., Rissanen, M., Jokinen, T., Schobesberger, S., Kangasluoma, J., Kontkanen, J., Nieminen, T., Kurtén, T., Nielsen, L. B., Jø gensen, S., Kjaergaard, H. G., Canagaratna, M., Maso, M. D., Berndt, T., Petäjä, T., Wahner, A., Kerminen, V.-M., Kulmala, M., Worsnop, D. R., Wildt, J., and Mentel, T. F.: A large source of low-volatility secondary organic aerosol, Nature, 506, 476-479, doi:10.1038/nature13032, 2014.

Ehrlich, H.-C. and Rarey, M.: Systematic benchmark of substructure search in molecular graphs - From Ullmann to VF2, Journal of Cheminformatics, 4, 13, doi:10.1186/1758-2946-4-13, 2012.

Enoch, S. J., Madden, J. C., and Cronin, M. T. D.: Identification of mechanisms of toxic action for skin sensitisation using a SMARTS pattern based approach, SAR and QSAR, Environ. Res., 19, 555-578, doi:10.1080/10629360802348985, 2008.

Fine, P. M., Cass, G. R., and Simoneit, B. R. T.: Chemical characterization of fine particle emissions from the fireplace combustion of woods grown in the southern United States, Environ. Sci. Technol., 36, 1442-1451, doi:10.1021/es0108988, 2002.

Fooshee, D. R., Nguyen, T. B., Nizkorodov, S. A., Laskin, J., Laskin, A., and Badi, P.: COBRA: A Computational Brewing Application for Predicting the Molecular Composition of Organic Aerosols, Environ. Sci. Technol., 46, 6048-6055, doi:10.1021/es3003734, 2012.

Fraser, M. P., Cass, G. R., Simoneit, B. R. T., and Rasmussen, R. A.: Air quality model evaluation data for organics. 5. C-6-C-22 nonpolar and semipolar aromatic compounds, Environ. Sci. Technol., 32, 1760-1770, doi:10.1021/es970349v, 1998.

Fraser, M. P., Cass, G. R., and Simoneit, B. R. T.: Air quality model evaluation data for organics. 6. C-3-C-24 organic acids, Environ. Sci. Technol., 37, 446-453, doi:10.1021/es0209262, 2003.

Griffin, R. J., Dabdub, D., Kleeman, M. J., Fraser, M. P., Cass, G. R., and Seinfeld, J. H.: Secondary organic aerosol - 3. Urban/regional scale model of size- and compositionresolved aerosols, J. Geophys. Res.-Atmos., 107, 4334, doi:10.1029/2001JD000544, 2002.

Grosjean, E., Grosjean, D., Fraser, M. P., and Cass, G. R.: Air quality model evaluation data for organics .3. Peroxyacetyl nitrate and peroxypropionyl nitrate in Los Angeles air, Environ. Sci. Technol., 30, 2704-2714, doi:10.1021/es9508535, 1996.

Hamilton, J. F., Webb, P. J., Lewis, A. C., Hopkins, J. R., Smith, S., and Davy, P.: Partially oxidised organic components in urban aerosol using GCXGC-TOF/MS, Atmos. Chem. Phys., 4, 1279 1290, doi:10.5194/acp-4-1279-2004, 2004.

Hann, M., Hudson, B., Lewell, X., Lifely, R., Miller, L., and Ramsden, N.: Strategic Pooling of Compounds for HighThroughput Screening, J. Chem. Inf. Comp. Sci., 39, 897-902, doi:10.1021/ci990423o, 1999.

Hawkins, L. N. and Russell, L. M.: Oxidation of ketone groups in transported biomass burning aerosol from the 2008 Northern California Lightning Series fires, Atmos. Environ., 44, 41424154, doi:10.1016/j.atmosenv.2010.07.036, 2010.

Henderson, B. H.: Kinetic Pre-Processor with updates to allow working with MCM, doi:10.5281/zenodo.44682, 2016.
Hennigan, C. J., Sullivan, A. P., Collett, J. L., and Robinson, A. L.: Levoglucosan stability in biomass burning particles exposed to hydroxyl radicals, Geophys. Res. Lett., 37, L09806, doi:10.1029/2010GL043088, 2010.

Heringa, M. F., DeCarlo, P. F., Chirico, R., Lauber, A., Doberer, A., Good, J., Nussbaumer, T., Keller, A., Burtscher, H., Richard, A., Miljevic, B., Prevot, A. S. H., and Baltensperger, U.: TimeResolved Characterization of Primary Emissions from Residential Wood Combustion Appliances, Environ. Sci. Technol., 46, 11418-11425, doi:10.1021/es301654w, 2012.

Herrmann, H., Tilgner, A., Barzaghi, P., Majdik, Z., Gligorovski, S., Poulain, L., and Monod, A.: Towards a more detailed description of tropospheric aqueous phase organic chemistry: CAPRAM 3.0, Atmos. Environ., 39, 4351-4363, doi:10.1016/j.atmosenv.2005.02.016, 2005.

Hildemann, L. M., Markowski, G. R., and Cass, G. R.: Chemical-composition of Emissions From Urban Sources of Fine Organic Aerosol, Environ. Sci. Technol., 25, 744-759, doi:10.1021/es00016a021, 1991.

Jayne, J. T., Leard, D. C., Zhang, X. F., Davidovits, P., Smith, K. A., Kolb, C. E., and Worsnop, D. R.: Development of an aerosol mass spectrometer for size and composition analysis of submicron particles, Aerosol Sci. Tech., 33, 49-70, doi:10.1080/027868200410840, 2000.

Jenkin, M. E.: Modelling the formation and composition of secondary organic aerosol from $\alpha$ - and $\beta$-pinene ozonolysis using MCM v3, Atmos. Chem. Phys., 4, 1741-1757, doi:10.5194/acp4-1741-2004, 2004.

Jenkin, M. E., Saunders, S. M., and Pilling, M. J.: The tropospheric degradation of volatile organic compounds: a protocol for mechanism development, Atmos. Environ., 31, 81-104, doi:10.1016/S1352-2310(96)00105-7, 1997.

Jenkin, M. E., Saunders, S. M., Wagner, V., and Pilling, M. J.: Protocol for the development of the Master Chemical Mechanism, MCM v3 (Part B): tropospheric degradation of aromatic volatile organic compounds, Atmos. Chem. Phys., 3, 181-193, doi:10.5194/acp-3-181-2003, 2003.

Kalberer, M., Sax, M., and Samburova, V.: Molecular size evolution of oligomers in organic aerosols collected in urban atmospheres and generated in a smog chamber, Environ. Sci. Technol., 40, 5917-5922, doi:10.1021/es0525760, 2006.

Kenny, P. W., Montanari, C. A., and Prokopczyk, I. M.: ClogPalk: a method for predicting alkane/water partition coefficient, Journal of Computer-Aided Molecular Design, 27, 389-402, doi:10.1007/s10822-013-9655-5, 2013.

Kerber, A., Laue, R., Meringer, M., Raocker, C., and Schymanski, E.: Mathematical Chemistry and Chemoinformatics: Structure Generation, Elucidation and Quantitative Structure-Property Relationships, Walter de Gruyter, Berlin, Germany, 2014.

Kroll, J. H., Donahue, N. M., Jimenez, J. L., Kessler, S. H., Canagaratna, M. R., Wilson, K. R., Altieri, K. E., Mazzoleni, L. R., Wozniak, A. S., Bluhm, H., Mysak, E. R., Smith, J. D., Kolb, C. E., and Worsnop, D. R.: Carbon oxidation state as a metric for describing the chemistry of atmospheric organic aerosol, Nature Chemistry, 3, 133-139, doi:10.1038/nchem.948, 2011.

Kroll, J. H., Lim, C. Y., Kessler, S. H., and Wilson, K. R.: Heterogeneous Oxidation of Atmospheric Organic Aerosol: Kinetics of Changes to the Amount and Oxidation State of Particle- 
Phase Organic Carbon, J. Phys. Chem. A, 119, 10767-10783, doi:10.1021/acs.jpca.5b06946, 2015.

Lai, C., Liu, Y., Ma, J., Ma, Q., and He, H.: Degradation kinetics of levoglucosan initiated by hydroxyl radical under different environmental conditions, Atmos. Environ., 91, 32-39, 2014.

Landrum, G.: RDKit: Open-source cheminformatics, available at: http://www.rdkit.org, last access: 30 September 2015.

Laskin, J., Eckert, P. A., Roach, P. J., Heath, B. S., Nizkorodov, S. A., and Laskin, A.: Chemical Analysis of Complex Organic Mixtures Using Reactive Nanospray Desorption Electrospray Ionization Mass Spectrometry, Anal. Chem., 84, 7179-7187, doi:10.1021/ac301533z, 2012.

Leithead, A., Li, S.-M., Hoff, R., Cheng, Y., and Brook, J.: Levoglucosan and dehydroabietic acid: Evidence of biomass burning impact on aerosols in the Lower Fraser Valley, Atmos. Environ., 40, 2721-2734, doi:10.1016/j.atmosenv.2005.09.084, 2006.

Lim, H. J. and Turpin, B. J.: Origins of primary and secondary organic aerosol in Atlanta: Results' of time-resolved measurements during the Atlanta supersite experiment, Environ. Sci. Technol., 36, 4489-4496, doi:10.1021/es0206487, 2002.

Liu, S., Takahama, S., Russell, L. M., Gilardoni, S., and Baumgardner, D.: Oxygenated organic functional groups and their sources in single and submicron organic particles in MILAGRO 2006 campaign, Atmos. Chem. Phys., 9, 6849-6863, doi:10.5194/acp9-6849-2009, 2009.

Maria, S. F., Russell, L. M., Turpin, B. J., and Porcja, R. J.: FTIR measurements of functional groups and organic mass in aerosol samples over the Caribbean, Atmos. Environ., 36, 5185-5196, doi:10.1016/S1352-2310(02)00654-4, 2002.

Maria, S. F., Russell, L. M., Turpin, B. J., Porcja, R. J., Campos, T. L., Weber, R. J., and Huebert, B. J.: Source signatures of carbon monoxide and organic functional groups in Asian Pacific Regional Aerosol Characterization Experiment (ACE-Asia) submicron aerosol types, J. Geophys. Res.-Atmos., 108, 8637, doi:10.1029/2003JD003703, 2003.

May, J. W. and Steinbeck, C.: Efficient ring perception for the Chemistry Development Kit, Journal of Cheminformatics, 6, 3, doi:10.1186/1758-2946-6-3, 2014.

Miloslav, N., Jiri, J., and Bedrich, K.: IUPAC Compendium of Chemical Terminology - the Gold Book, available at: http:// goldbook.iupac.org, last access: 30 September 2015.

Ming, Y. and Russell, L. M.: Predicted hygroscopic growth of sea salt aerosol, J. Geophys. Res.-Atmos., 106, 28259-28274, doi:10.1029/2001JD000454, 2001.

Nguyen, T. B., Nizkorodov, S. A., Laskin, A., and Laskin, J.: An approach toward quantification of organic compounds in complex environmental samples using high-resolution electrospray ionization mass spectrometry, Analytical Methods, 5, 72-80, doi:10.1039/c2ay25682g, 2013.

O'Boyle, N. M., Morley, C., and Hutchison, G. R.: Pybel: a Python wrapper for the OpenBabel cheminformatics toolkit, Chem. Cent. J., 2, 5, doi:10.1186/1752-153X-2-5, 2008.

O’Boyle, N. M., Banck, M., James, C. A., Morley, C., Vandermeersch, T., and Hutchison, G. R.: Open Babel: An open chemical toolbox, Journal of Cheminformatics, 3, 33, doi:10.1186/17582946-3-33, 2011

Olah, M., Bologa, C., and Oprea, T.: An automated PLS search for biologically relevant QSAR descriptors, J. Comput. Aid. Mol. Des., 18, 437-449, doi:10.1007/s10822-004-4060-8, 2004.
Paatero, P. and Tapper, U.: Positive Matrix Factorization A Nonnegative Factor Model With Optimal Utilization of Error-estimates of Data Values, Environmetrics, 5, 111-126, doi:10.1002/env.3170050203, 1994.

Pankow, J. F. and Asher, W. E.: SIMPOL.1: a simple group contribution method for predicting vapor pressures and enthalpies of vaporization of multifunctional organic compounds, Atmos. Chem. Phys., 8, 2773-2796, doi:10.5194/acp-8-27732008, 2008.

Pankow, J. F. and Barsanti, K. C.: The carbon numberpolarity grid: A means to manage the complexity of the mix of organic compounds when modeling atmospheric organic particulate matter, Atmos. Environ., 43, 2829-2835, doi:10.1016/j.atmosenv.2008.12.050, 2009.

Pavia, D., Lampman, G., and Kriz, G.: Introduction to Spectroscopy, Brooks/Cole Pub Co., 2008.

Pence, H. E. and Williams, A.: ChemSpider: An Online Chemical Information Resource, J. Chem. Educ., 87, 1123-1124, doi:10.1021/ed100697w, 2010.

Radzi bin Abas, M., Oros, D. R., and Simoneit, B. R. T.: Biomass burning as the main source of organic aerosol particulate matter in Malaysia during haze episodes, Chemosphere, 55, 1089-95, doi:10.1016/j.chemosphere.2004.02.002, 2004.

Raventos-Duran, T., Camredon, M., Valorso, R., Mouchel-Vallon, C., and Aumont, B.: Structure-activity relationships to estimate the effective Henry's law constants of organics of atmospheric interest, Atmos. Chem. Phys., 10, 7643-7654, doi:10.5194/acp10-7643-2010, 2010.

Rogge, W. F., Hildemann, L. M., Mazurek, M. A., Cass, G. R., and Simoneit, B. R. T.: Sources of Fine Organic Aerosol .2. Noncatalyst and Catalyst-equipped Automobiles and Heavyduty Diesel Trucks, Environ. Sci. Technol., 27, 636-651, doi:10.1021/es00041a007, 1993.

Rogge, W. F., Hildemann, L. M., Mazurek, M. A., Cass, G. R., and Simoneit, B. R. T.: Sources of fine organic aerosol. 9. Pine, oak and synthetic log combustion in residential fireplaces, Environ. Sci. Technol., 32, 13-22, doi:10.1021/es960930b, 1998.

Ruggeri, G., Bernhard, F. A., Henderson, B. H., and Takahama, S.: Model-measurement comparison of functional group abundance in a-pinene and 1,3,5-trimethylbenzene secondary organic aerosol formation, Atmos. Chem. Phys. Discuss., doi:10.5194/acp-2016-46, in review, 2016.

Russell, L. M.: Aerosol organic-mass-to-organic-carbon ratio measurements, Environ. Sci. Technol., 37, 2982-2987, doi:10.1021/es026123w, 2003.

Russell, L. M., Bahadur, R., Hawkins, L. N., Allan, J., Baumgardner, D., Quinn, P. K., and Bates, T. S.: Organic aerosol characterization by complementary measurements of chemical bonds and molecular fragments, Atmos. Environ., 43, 61006105, doi:10.1016/j.atmosenv.2009.09.036, 2009.

Russell, L. M., Bahadur, R., and Ziemann, P. J.: Identifying organic aerosol sources by comparing functional group composition in chamber and atmospheric particles, P. Natl. Acad. Sci. USA, 108, 3516-3521, doi:10.1073/pnas.1006461108, 2011.

Sandu, A. and Sander, R.: Technical note: Simulating chemical systems in Fortran90 and Matlab with the Kinetic PreProcessor KPP-2.1, Atmos. Chem. Phys., 6, 187-195, doi:10.5194/acp-6187-2006, 2006. 
Saunders, S. M., Jenkin, M. E., Derwent, R. G., and Pilling, M. J.: Protocol for the development of the Master Chemical Mechanism, MCM v3 (Part A): tropospheric degradation of nonaromatic volatile organic compounds, Atmos. Chem. Phys., 3, 161-180, doi:10.5194/acp-3-161-2003, 2003.

Schilling Fahnestock, K. A., Yee, L. D., Loza, C. L., Coggon, M. M., Schwantes, R., Zhang, X., Dalleska, N. F., and Seinfeld, J. H.: Secondary Organic Aerosol Composition from C12 Alkanes, J. Phys. Chem. A, 119, 4281-4297, doi:10.1021/jp501779w, 2015.

Seinfeld, J. H. and Pandis, S. N.: Atmospheric Chemistry and Physics: From Air Pollution to Climate Change, John Wiley \& Sons, New York, 2nd Edn., 2006.

Shiraiwa, M., Berkemeier, T., Schilling-Fahnestock, K. A., Seinfeld, J. H., and Pöschl, U.: Molecular corridors and kinetic regimes in the multiphase chemical evolution of secondary organic aerosol, Atmos. Chem. Phys., 14, 8323-8341, doi:10.5194/acp-14-8323-2014, 2014.

Simoneit, B. R. T.: A review of biomarker compounds as source indicators and tracers for air pollution, Environ. Sci. Pollut. R., 6, 159-169, doi:10.1007/BF02987621, 1999.

Steinbeck, C., Han, Y., Kuhn, S., Horlacher, O., Luttmann, E., and Willighagen, E.: The Chemistry Development Kit (CDK): An Open-Source Java Library for Chemo- and Bioinformatics, J. Chem. Inf. Comp. Sci., 43, 493-500, doi:10.1021/ci025584y, 2003.

Suda, S. R., Petters, M. D., Yeh, G. K., Strollo, C., Matsunaga, A., Faulhaber, A., Ziemann, P. J., Prenni, A. J., Carrico, C. M., Sullivan, R. C., and Kreidenweis, S. M.: Influence of Functional Groups on Organic Aerosol Cloud Condensation Nucleus Activity, Environ. Sci. Technol., doi:10.1021/es502147y, 2014.

Swain, M.: ChemSpiPy, available at: http://chemspipy.readthedocs. org, last access: 30 September 2015.

Takahama, S.: APRL Substructure Search Program, doi:10.5281/zenodo.34975, 2015.

Topping, D., Barley, M., Bane, M. K., Higham, N., Aumont, B., Dingle, N., and McFiggans, G.: UManSysProp v1.0: an online and open-source facility for molecular property prediction and atmospheric aerosol calculations, Geosci. Model Dev., 9, 899914, doi:10.5194/gmd-9-899-2016, 2016.

Vogel, A. L., Äijälä, M., Corrigan, A. L., Junninen, H., Ehn, M., Petäjä, T., Worsnop, D. R., Kulmala, M., Russell, L. M., Williams, J., and Hoffmann, T.: In situ submicron organic aerosol characterization at a boreal forest research station during HUMPPA-COPEC 2010 using soft and hard ionization mass spectrometry, Atmos. Chem. Phys., 13, 10933-10950, doi:10.5194/acp-13-10933-2013, 2013.

Walters, W. and Murcko, M. A.: Prediction of "drug-likeness", Adv. Drug Deliver. Rev., 54, 255-271, doi:10.1016/S0169409X(02)00003-0, 2002.
Weininger, D.: Smiles, A Chemical Language and Informationsystem .1. Introduction To Methodology and Encoding Rules, J. Chem. Inf. Comp. Sci., 28, 31-36, doi:10.1021/ci00057a005, 1988.

Williams, B. J., Goldstein, A. H., Kreisberg, N. M., and Hering, S. V.: An in-situ instrument for speciated organic composition of atmospheric aerosols: Thermal Desorption Aerosol GC/MS-FID (TAG), Aerosol Sci. Tech., 40, 627-638, doi:10.1080/02786820600754631, 2006.

Yatavelli, R. L. N., Stark, H., Thompson, S. L., Kimmel, J. R., Cubison, M. J., Day, D. A., Campuzano-Jost, P., Palm, B. B., Hodzic, A., Thornton, J. A., Jayne, J. T., Worsnop, D. R., and Jimenez, J. L.: Semicontinuous measurements of gas-particle partitioning of organic acids in a ponderosa pine forest using a MOVI-HRToFCIMS, Atmos. Chem. Phys., 14, 1527-1546, doi:10.5194/acp14-1527-2014, 2014.

Yeh, G. K. and Ziemann, P. J.: Gas-Wall Partitioning of Oxygenated Organic Compounds: Measurements, StructureActivity Relationships, and Correlation with Gas Chromatographic Retention Factor, Aerosol Sci. Tech., 49, 727-738, doi:10.1080/02786826.2015.1068427, 2015.

Zhang, Q., Jimenez, J. L., Canagaratna, M. R., Allan, J. D., Coe, H., Ulbrich, I., Alfarra, M. R., Takami, A., Middlebrook, A. M., Sun, Y. L., Dzepina, K., Dunlea, E., Docherty, K., DeCarlo, P. F., Salcedo, D., Onasch, T., Jayne, J. T., Miyoshi, T., Shimono, A., Hatakeyama, S., Takegawa, N., Kondo, Y., Schneider, J., Drewnick, F., Borrmann, S., Weimer, S., Demerjian, K., Williams, P., Bower, K., Bahreini, R., Cottrell, L., Griffin, R. J., Rautiainen, J., Sun, J. Y., Zhang, Y. M., and Worsnop, D. R.: Ubiquity and dominance of oxygenated species in organic aerosols in anthropogenically-influenced Northern Hemisphere midlatitudes, Geophys. Res. Lett., 34, L13801, doi:10.1029/2007GL029979, 2007.

Zuend, A., Marcolli, C., Luo, B. P., and Peter, T.: A thermodynamic model of mixed organic-inorganic aerosols to predict activity coefficients, Atmos. Chem. Phys., 8, 4559-4593, doi:10.5194/acp8-4559-2008, 2008.

Zuend, A., Marcolli, C., Booth, A. M., Lienhard, D. M., Soonsin, V., Krieger, U. K., Topping, D. O., McFiggans, G., Peter, T., and Seinfeld, J. H.: New and extended parameterization of the thermodynamic model AIOMFAC: calculation of activity coefficients for organic-inorganic mixtures containing carboxyl, hydroxyl, carbonyl, ether, ester, alkenyl, alkyl, and aromatic functional groups, Atmos. Chem. Phys., 11, 9155-9206, doi:10.5194/acp11-9155-2011, 2011. 